\title{
La guerra civil siria y el papel de las Naciones Unidas ${ }^{1}$
}

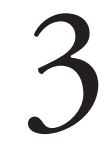

https://doi.org/10.21830/9789585318328.03

\author{
Manuel Rayran Cortés \\ Escuela Militar de Cadetes "General José María Córdova”
}

\section{Resumen}

Desde 2011, la República Árabe de Siria ha estado inmersa en un conflicto armado cuyas características particulares han obligado a evaluar las acciones de las instituciones internacionales para garantizar la paz internacional. Con el fin de comprender de manera clara los orígenes de los enfrentamientos bélicos, en este capítulo se explican los hitos, quiénes fueron los actores principales y sus intereses; además, se determina la naturaleza de la guerra. De igual manera, se analiza el papel del Consejo de Seguridad de Naciones Unidas, sus dificultades para resolver el conflicto y el protagonismo de las organizaciones regionales, así como de otras instituciones subsidiarias de las Naciones Unidas, para reducir la guerra. Por último, se evidencian las fallas estructurales de la seguridad colectiva, se muestra cómo los intereses geopolíticos en el seno de las instituciones causan daños irreparables a la población civil y se exponen las razones por las cuales este tipo de guerras son el resultado de un debilitamiento del Estado.

Palabras clave: geopolítica; Organización de Naciones Unidas; República Árabe de Siria; resolución de conflictos; globalización.

1 Este capítulo hace parte de los resultados del proyecto de investigación "Mecanismos del sistema de Naciones Unidas para la resolución de conflictos armados contemporáneos", del Grupo de Investigación en Ciencias Militares de la Escuela Militar de Cadetes "General José María Cordova", registrado con el código COL0082556 de Minciencias. Los puntos de vista y los resultados de este artículo pertenecen al autor $\mathrm{y}$ no reflejan necesariamente los de las instituciones participantes.

2 Magíster en Ciencias Políticas orientadas a las Relaciones Internacionales con especialidad en Diplomacia y Resolución de Conflictos (Universidad Católica de Lovaina, Bélgica). Docente de la Facultad de Relaciones Internacionales de la Escuela Militar de Cadetes "General José María Córdova". Docente de la Facultad de Finanzas, Gobierno y Relaciones Internacionales (Universidad Externado de Colombia). Sus líneas de investigación son: teoría de las relaciones internacionales, teoría de los conflictos, seguridad internacional, geopolítica de las potencias y resolución de conflictos. ORCID: https://orcid. org/0000-0003-3658-2690 - Contacto: manuel.rayran@esmic.edu.co 


\section{Introducción}

A partir de marzo de 2011, la República Árabe de Siria ha estado inmersa en un conflicto bélico sin precedentes desde su independencia. La guerra civil siria, si bien inició debido a las justas reivindicaciones internas de sus ciudadanos, escaló a niveles internacionales, con actores de diferente naturaleza y una mezcla de intereses geopolíticos que dejaron consecuencias devastadoras para los civiles.

Según cifras de la Oficina de Asuntos Humanitarios de las Naciones Unidas, los horrores de este enfrentamiento armado han hecho que más de la mitad de la población abandone sus hogares, 6.1 millones de personas estén refugiados en otros países, otros 6.5 millones se hayan desplazado dentro del territorio nacional y unos 13.1 millones más necesiten protección. Este conjunto de factores políticos y militares llevaron a que el conflicto sirio ocupara la atención de los principales tabloides del mundo, de las aulas de las instituciones universitarias, de la agenda política internacional y de los debates de las diferentes organizaciones internacionales, como la Organización de Naciones Unidas (en adelante ONU) y sus órganos subsidiarios.

El Consejo de Seguridad de las Naciones Unidas (en adelante CSNU), por ejemplo, ha adoptado veintitrés resoluciones sobre Siria desde que iniciaron los enfrentamientos, y en 2017 fue el tema de mayor frecuencia en este órgano, pues se trató treinta y tres veces el tema en consultas oficiosas. De igual manera, las diferentes agencias de la ONU han logrado ingresar convoyes con ayuda humanitaria que llegaron a beneficiar a 820.000 personas, 2.5 millones de niños fueron vacunados contra la polio y otros 4.8 millones contra el sarampión.

No obstante, a pesar de los diferentes esfuerzos realizados por las instituciones humanitarias internacionales durante estos ocho años de conflicto armado, la guerra civil siria no ha terminado, a causa de los intereses geopolíticos de las potencias globales que han obstaculizado las soluciones en el CSNU, órgano encargado de mantener la paz y seguridad internacionales. Por todo lo anterior, el presente texto estará orientado por las siguientes preguntas: ¿cuáles fueron los orígenes de la guerra civil siria?, ¿quiénes son sus actores y cuáles sus intereses?, ¿cuál es la naturaleza del conflicto bélico sirio?, ¿cuál ha 
sido el rol que ha jugado las Naciones Unidas y por qué el CSNU no ha logrado aplicar los mecanismos de solución de controversias consagrado en la Carta de San Francisco?

Para dar respuesta a estas cuestiones, este capítulo utiliza una metodología cualitativa y está divido en tres secciones. En la primera parte, con el fin de entender mejor la guerra civil siria, se analizarán los principales hitos del conflicto, los actores involucrados y sus respectivos intereses, para luego profundizar en la naturaleza de esta guerra. En la segunda parte se estudiará el papel que la ONU ha jugado dentro del enfrentamiento armado. En la tercera parte, se examinará la evolución y resolución de la guerra civil siria. Por último, se esgrimen algunas consideraciones finales.

\section{Conflicto armado sirio}

\section{Elementos preliminares}

Con el fin de comprender de manera clara el conflicto sirio, es necesario describir dos elementos preliminares básicos, a saber: la ubicación geográfica y los hechos históricos que dieron origen la conformación del país como república independiente.

A lo largo de los siglos, la ubicación geográfica de la República Árabe de Siria ha sido de importancia capital. Este país se ubica en la región de Oriente Próximo ${ }^{3}$ y cuenta con una extensión territorial de $185.180 \mathrm{~m}^{2}$. En términos geopolíticos, su posición lo convierte en un territorio estratégico por tres razones: primero, es la entrada marítima más cercana desde Europa a través del mar Mediterráneo; segundo, de sus cinco límites terrestres con países vecinos su frontera más larga es con Turquía, país tapón entre dos regiones del mundo con culturas e identidades bien marcadas (figura 1), y tercero, es una superficie que por su ubicación facilitaría la construcción de nuevas rutas de gas y petróleo para abastecer a Europa, lo que le permitiría al viejo continente reducir su dependencia de recursos energéticos de Rusia.

3 Los países que comprenden la región de Oriente Próximo son: Arabia Saudita, Bahréin, Chipre, Egipto, Emiratos Árabes Unidos, Irán, Irak, Israel, Jordania, Kuwait, Líbano, Omán, Qatar, Siria, Sudán y Yemen. 


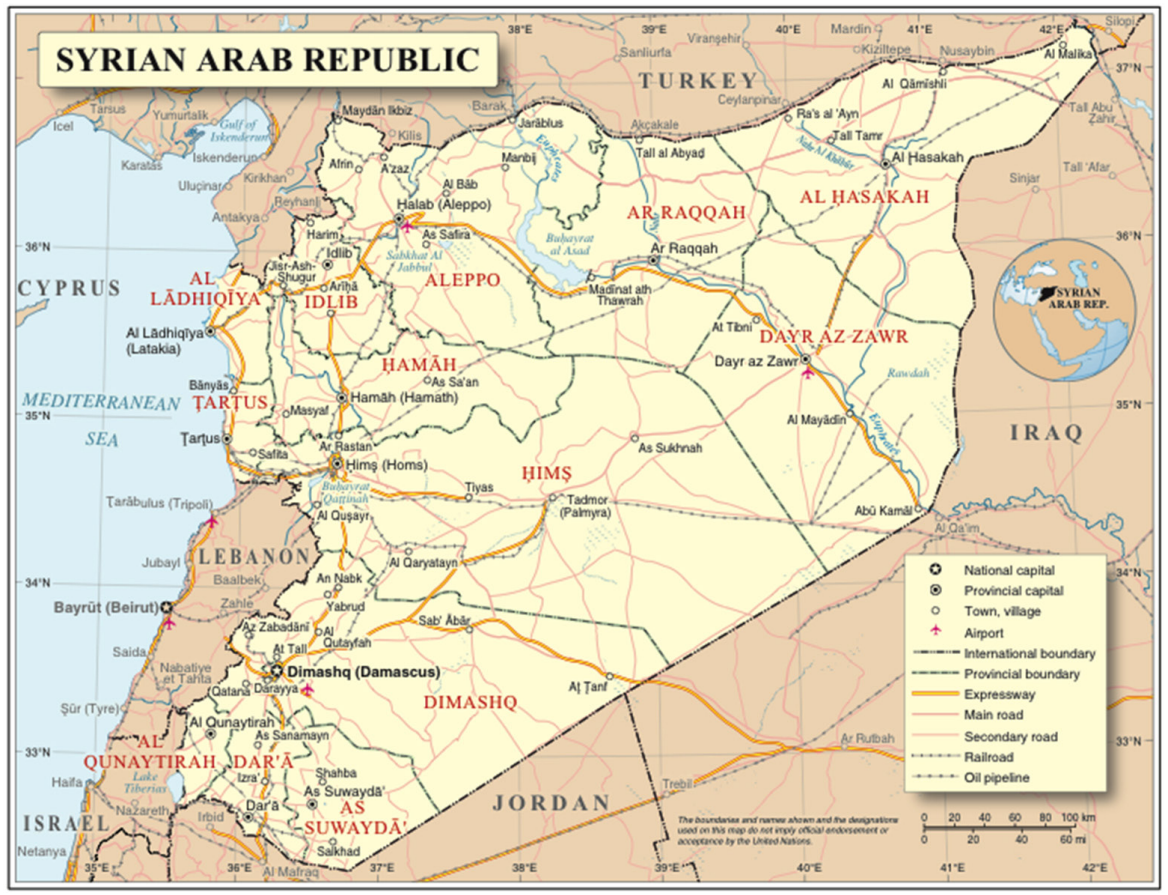

Figura 1. Mapa de la República Árabe de Siria

Fuente: Naciones Unidas (2012)

En términos históricos, durante años Siria ha estado en medio de la disputa territorial entre Francia ${ }^{44}$ e Inglaterra, que, sin embargo, una vez unidos durante la Primera Guerra Mundial para derrocar el Imperio otomano, deciden dividirse la región. Es así que, en mayo de 1916, a través del acuerdo secreto firmado por el excónsul francés, François Georges-Picot, y el emisario del Ministerio de Guerra británico, Mark Sykes, estas dos naciones se reparten

4 Es de suma importancia recalcar que ha sido desde Siria que Francia ha podido tener mayor contacto e influencia en la región de Oriente Próximo. En 1860, Francia denuncia la pasividad y permisividad del Imperio otomano frente a las masacres perpetradas contra el pueblo cristiano maronita en aquella provincia del Imperio. Ante esta situación, Francia interviene sobre el lugar. Este acto es considerado como la primera acción militar justificada con argumentos humanitarios, pero con una alta presencia de intereses políticos y económicos (Goutalier, 2017). Francia se interesa en cuatro grandes ciudades al interior de Siria que formarán, hasta hoy, la columna vertebral del acceso a la región petrolífera de Mosul, en Irak, estas son: Damas, Homs, Hama y Alepo. Este corredor también cumpliría dos objetivos geopolíticos para Francia: primero, tener un acceso desde el mar Mediterráneo hasta las fronteras persas y, segundo, convertir esa circunscripción geográfica en una zona tapón, con el fin de paralizar las ganancias territoriales de Gran Bretaña en el sur y de Rusia en el norte. 
los territorios de la región con la creación de nuevos Estados, lo que les permitiría tener un control con carácter imperial sobre esta zona del mundo, caracterizada por su alta cantidad de materias primas. Como consecuencia, el Supremo Consejo de los Aliados le otorga a Francia el protectorado de Siria, el cual terminaría en 1943 con la creación de dos entidades independientes: Siria y Líbano. No obstante, Francia abandona de manera definitiva el suelo sirio al retirar sus soldados en 1946.

A partir de ese año, Siria vivió diferentes golpes de Estado y discusiones políticas, dinámica que en 1961 se materializó con un referéndum constitucional que dio nacimiento oficial a la República Árabe de Siria. No obstante, este documento no logró evitar la inestabilidad interna, de ahí que para 1963 se presentara un nuevo golpe, lo que le permitió al partido político Baaz Árabe Socialista tomar la dirección del Estado. A partir de ese año y hasta 1970, Háfez al-Asad, miembro de esa organización política y padre del actual presidente sirio Bashar al-Asad, desarrolla una carrera militar ascendente, lo que le permite aumentar su importancia en el país y aprovechar su posición para llegar al poder en 1970, por medio de otro golpe militar.

En ese sentido, desde 1970 hasta la actualidad la familia Al-Asad ha estado al mando del Gobierno sirio. Para mantenerse en el poder durante tanto tiempo, los Al-Asad han utilizado herramientas tales como que la Constitución de 1973 reconociera el Baaz como el partido dirigente de la sociedad siria, servirse del credo alawí ${ }^{5}$ (vertiente del chiismo) ${ }^{6}$ y su cercanía con la familia para entregar cargos públicos de alto nivel, mantener y agudizar las medidas del estado de emergencia, apoyarse en el poder militar y en las élites económicas, desarrollar nuevas milicias al servicio del Estado y crear al menos doce agencias de seguridad (De Currea-Lugo, 2019). La edificación de esta estructura política, en ese sentido, ha convertido de manera progresiva el Estado sirio en un prototipo de república hereditaria.

5 Siria tiene una historia milenaria, de ahí que su riqueza cultural y religiosa sea de suma importancia. La composición de los cultos en esta nación está dividida por un $87 \%$ de musulmanes, $10 \%$ de cristianos y $3 \%$ de drusos. En lo que respecta a los musulmanes, el $74 \%$ son sunitas y $13 \%$ chiitas.

6 Con el fin de comprender las características de las divisiones religiosas en Oriente Próximo, se recomienda leer el libro Los rostros del otro. Colonialismo y construcción social en Medio Oriente y Norte de África, publicado por la Universidad Externado de Colombia en 2019. 
Es importante resaltar que, si bien todas las anteriores herramientas ayudaron para que Háfez al-Asad se mantuviera en el poder, la instrumentalización de la heterogeneidad religiosa jugó un papel protagónico, ya que le permitió dividir a la población y ganarse la lealtad de unas comunidades frente a otras. Esta dinámica se comprende mejor cuando se tiene en cuenta que el exmandatario sirio y su familia pertenecen a la minoría musulmana chiita-alawita, lo que genera cierta controversia a nivel interno con el sunismo, que es la mayoría de la población siria. No obstante, a pesar de esta discrepancia confesional, la razón del origen de la guerra civil siria en 2011 no fue de carácter religioso, como algunos medios de comunicación y analistas así lo quieren presentar.

\section{Principales hitos de la guerra civil siria}

En el año 2000, tras la muerte de Háfez al-Azad, su hijo Bashar al-Asad asume el poder. A pesar de que al inicio de su gobierno generó una esperanza de cambio, ya que para finales de ese año liberó algunos presos políticos y luego, en 2001, permitió la formación de la Asociación de Derechos Humanos y publicó el primer periódico independiente; Bashar al-Asad rápidamente reafirmó dos acciones que han marcado su mandato: el régimen autoritario y la profundización del modelo económico neoliberal, con lo que empeoró la situación económica del país y alimentó el inconformismo del pueblo sirio.

Con respecto al régimen autoritario, los ataques políticos de Bashar al-Asad se profundizaron entre 2006 y 2008, cuando ordenó encarcelar a los firmantes de la Declaración de Damasco, con la que solicitaban acabar con el estado de emergencia, exigían una mayor libertad de expresión y abogaban por un Estado laico. De igual manera, el gobierno despótico se fortaleció en la medida en que los nuevos cuerpos de seguridad de inteligencia — que están en manos de familiares o de personas cercanas al jefe de Estado- intimidaban a los grupos políticos que intentaban desalojar del poder a los Asad, y ejercían mayor control dentro de las fuerzas armadas.

En relación con lo económico, cuando Bashar llega al poder la situación económica de Siria era lamentable, motivo por el que durante sus dos primeros años de mandato moderniza la estructura gubernamental, se rodea 
de personas de confianza y logra pasar de un modelo económico estatizado a uno de libre mercado, con la privatización de empresas de diferentes sectores y fincas agropecuarias (De Currea-Lugo, 2019). Los más beneficiados por este cambio fueron sus familiares o los empresarios cercanos a aquellos, como, por ejemplo, su primo Rami Majluf, quien logró controlar más del 60\% de la economía y aglutinar una inmensa fortuna con el conglomerado Cham y la compañía telefónica móvil Syriatel (Álvarez-Ossorio, 2017). A esto se agregan tres elementos que agudizaron la mala situación económica del pueblo sirio: las sequias, que llevaron a los campesinos a abandonar sus tierras porque el Estado no los ayudó; los altos niveles de corrupción; y la falta de oportunidades para los jóvenes. Respecto a la corrupción, según Transparencia Internacional, el índice de corrupción de Siria ha estado entre los más altos desde 2004, pues se ha ubicado entre los cincuenta países más corruptos del mundo. Por último, y en relación con la juventud, según el Programa de Desarrollo de las Naciones (en adelante PNUD) (citado en Álvarez-Ossorio, 2017), el 55\% de la población siria está conformado por jóvenes, sector poblacional que presenta mayor dificultad para vincularse al mercado laboral.

Así las cosas, la suma de diversos problemas -económicos, de desigualdad, de corrupción, de una alta militarización del Estado, de la agudización del régimen autoritario y de un ambiente de revueltas presentadas en países de la región como Túnez, Egipto, Libia, Bahréin y Yemen- llevó a que la población siria, de manera espontánea, manifestara también su inconformismo con respecto al gobierno de Bashar. Lo que condujo a que, el 6 de marzo de 2011, catorce jóvenes en la ciudad de Daraa, cerca de la frontera con Jordania, pintaran varios grafitis con la consigna: "El pueblo quiere la caía el régimen" (Gutiérrez, 2015; De Currea-Lugo, 2019). Por este hecho, los estudiantes fueron arrestados y torturados por las agencias de seguridad del Estado, lo que generó el repudio de parte de los familiares de las víctimas y de la sociedad en general.

Estas arbitrariedades se conocieron en otras ciudades de Siria, lo que llevó a que, de manera progresiva, las distintas urbes se sumaran a las manifestaciones pacíficas. Para el inicio de las protestas, las consignas políticas estaban direccionadas a pequeñas reformas y no a cambiar el régimen, pues, 
para este momento, los manifestantes sabían que, para crear un diálogo con el Gobierno, la permanencia de Bashar al-Asad en el poder no estaba en consideración. Sin embargo, pasaron solo unos meses para que algunos sectores de la oposición consideraran que la condición básica para la negociación sería la salida obligatoria de Bashar del Estado.

Si bien es cierto que los días siguientes a las manifestaciones la ciudadanía logró organizarse en comités locales ${ }^{7}$, los grupos de oposición no eran tan representativos, la propuesta del diálogo que se planteaba no era incluyente $y$, a pesar de una mayor participación de la población siria, las posiciones políticas estaban divididas en dos, a saber: un sector secular, en particular el partido comunista, que consideraba que el método a utilizar para las reformas se lograría a través del diálogo y los argumentos; y algunos sectores que reconocían el fracaso de los métodos no violentos y consideraban que la mejor opción era pasar a la lucha armada.

Esta última tendencia se fortaleció cuando el presidente Bashar, en vez de escuchar los justos reclamos y hacer pequeñas reformas, prefirió abordar las manifestaciones con alta represión y agresión hacia la población. Esta respuesta de parte del Gobierno hizo que de manera sucesiva se radicalizara el conflicto hasta transformarse en una guerra civil interna, y, posteriormente, en un conflicto bélico con influencia e intereses de países externos.

De acuerdo con Gutiérrez (2015), el primer incidente de rebelión armada abierta se produjo en junio de 2011 en cercanías a la frontera con Turquía, en donde los locales tomaron las armas de la comisaría de policía para defenderse de los disparos de las autoridades del Estado. Los civiles armados se fortalecieron, gracias a que un número considerable de integrantes del grupo de militares que fueron enviados a esta zona desertaron y utilizaron sus armas para luchar contra las fuerzas de seguridad. Para septiembre del mismo año, esta situación se replicó en las ciudades de Homs y Jabel al Zaqiya; luego, en enero de 2012, pasó a los suburbios de la capital Damasco; después, en julio de ese año, a Alepo y así sucesivamente, hasta extenderse a toda Siria. Para

7 Es importante recordar que la sociedad siria sacrificó durante décadas la discusión y las libertades políticas a cambio de algunos beneficios económicos y cierta estabilidad. Por tal razón, a la sociedad en general le costó tanto poder llegar a acuerdos políticos y desarrollar debates más cualificados, que les permitieran determinar con mayor claridad y solidez el rumbo del país en esa transición. 
julio de 2012, el Comité Internacional de la Cruz Roja (CICR) ya calificaba la situación siria como un conflicto armado interno o guerra civil. De igual manera, en la medida en que pasaba el tiempo y los grupos armados opositores se expandían por el territorio sirio, la intervención de otros Estados empezó a tener mayor relevancia, pues estos crearon, financiaron o entrenaron organizaciones bélicas que buscaban derrocar al presidente Bashar al-Asad o, por el contrario, mantenerlo en el poder.

Como ejemplo de lo anterior, se puede mencionar a países de la región, como Arabia Saudita, Qatar e Israel, que financiaron o apoyaron a grupos rebeldes radicales que buscaban derrocar a Bashar al-Asad; mientras que Irán, con su organización Hizbulah, respaldó al régimen. En términos de las potencias de la ordenanza mundial, a partir de 2014 Estados Unidos, Reino Unido, Francia y otros seis países participaron en la guerra civil siria, apoyando a las Fuerzas Democráticas Sirias (coalición militar rebelde integrada por el Ejército kurdo y árabes). Ahora bien, para 2015, con el fin de contrarrestar las acciones de Estados Unidos y sus aliados en la región —que buscaban derrocar a al-Asad—, Rusia decide intervenir de manera directa en la guerra civil, dándole el respaldo inmediato al régimen y atacando de manera frontal al Estado Islámico de Irak y el Levante y otros grupos rebeldes islámicos.

Ahora bien, una vez comprendidas las causas del conflicto y los principales hitos, en la siguiente subsección se presentarán los actores e intereses que se dan cita en el conflicto bélico sirio.

\section{Actores e intereses}

El conflicto sirio no solo se ha caracterizado por sus impactos negativos en los civiles, por la naturaleza de su origen, por el alto número de sus protagonistas — que se han transformado en el tiempo-, o por las estrategias que han aplicado las diferentes potencias regionales o de ordenanza mundial para obtener ganancias, sino que también, se ha distinguido porque ha estado determinado por lo que ahora se conoce como posverdad ${ }^{8}$. Es decir, un sinfín

8 Cada año, el Diccionario Oxford presenta la palabra que durante los doce meses reflejó las tendencias o los cambios importantes en el idioma inglés. Para el 2016, la palabra seleccionada fue 'posverdad' que, resumiendo, se entiende como: engaño. Este término fue elegido por la manera como los 
de afirmaciones que no están ceñidas a los hechos reales, lo que ha llevado a que la opinión pública haya sido desinformada por medio de mentiras que, en muchas ocasiones, son replicadas por los diferentes medios de comunicación. Por tales motivos, y para hacer más claros varios asuntos, en el primer apartado de esta sección serán presentados los participantes y sus diferentes intereses dentro del conflicto bélico en Siria. Para facilitar la comprensión, los actores se reunirán en tres grandes ejes, a saber: el Gobierno sirio, las organizaciones políticas y armadas opositoras, y las potencias de la ordenanza mundial.

\section{El gobierno de Bashar al-Asad}

Debido a que con el tiempo el conflicto sirio escaló su nivel de complejidad, los objetivos políticos y militares también se transformaron. En ese sentido, en el momento en el que surgieron las manifestaciones del pueblo sirio por la tortura de los catorce jóvenes, Bashar al-Asad, en vez de pedir disculpas a las víctimas y prometer algún castigo para los perpetradores de esos hechos, prefirió tildar a las manifestaciones como un complot internacional contra su gobierno, razón por la cual decidió apaciguarlas con extrema violencia (ÁlvarezOssorio, 2017). Para ese momento de la crisis interna, el objetivo político de Bashar era reducir todo brote político que pudiera desestabilizar su gobierno, lo que significaba, en términos militares, reestablecer el orden interno y ratificar a las fuerzas del orden como depositarias del poder para ejercer autoridad sobre la sociedad. No obstante, y a pesar de que su primera respuesta no fue la más prudente y esperada por la población, tampoco se puede desconocer que Bashar creó algunos lazos de comunicaciones con los opositores y realizó algunas reformas, pero fueron insustanciales.

Una vez la crisis política interna se transformó en una guerra civil, caracterizada por un número considerable de grupos armados bien financiados y con alta presencia en las diferentes regiones de Siria, los objetivos de Bashar al-Asad cambiaron; así, su objetivo político pasó ser cómo evitar su salida del poder por medio del derrocamiento; y su objetivo militar se encaminó a evitar

organizadores de la campaña del hoy presidente Donald Trump, en Estados Unidos, y del movimiento en para ganar el Brexit, en Reino Unido, utilizaron improperios y mentiras para que la población los apoyara en sus objetivos políticos. 
un golpe de Estado y a enfrentar a todos los grupos armados que le hacían frente. Con el fin de lograr las anteriores metas, Bashar aplicó dos estrategias: una dirigida a lo militar y otra a la diplomacia.

Con relación a la primera estrategia, para evitar que la población continuara adhiriéndose a los grupos rebeldes, el régimen atacó a su propia población con una operación de tierra quemada ${ }^{9}$ en las zonas donde se ubicaban los sirios alzados en armas. Esta acción, sumada a los bombardeos indiscriminados y el uso de armas químicas ${ }^{10}$ dejaron como resultado un elevado número de fallecidos, y causaron que miles de sirios tuvieran que desplazarse dentro o fuera del país en búsqueda de un refugio. Ahora bien, en lo que respecta a lo diplomático, debido al financiamiento realizado por las potencias regionales a los rebeldes para buscar la caída de Bashar, el régimen recurrió a la firma de acuerdos con otras potencias regionales y de la ordenanza mundial para equilibrar la situación. En ese sentido, Rusia e Irán se convirtieron en los principales aliados del Gobierno sirio para enfrentar la coyuntura. Es claro que la incursión de estos dos actores no está motivada por un acercamiento ideológico con Bashar al-Asad, por el contrario, su participación obedece a agendas políticas e intereses propios que apuntan a una configuración política en la región y el mundo, como se explicará en los siguientes acápites.

\section{Organizaciones políticas y armadas opositoras}

La alta desinformación, las noticias falsas, el poco conocimiento sobre la región y los sesgos ideológicos y religiosos han hecho que, para muchos, sea difícil comprender la conformación estructural de la oposición siria. Como consecuencia de lo anterior, observadores de la vida internacional simplifican

9 Una operación de tierra quemada es una táctica militar con la que se busca destruir todo lo que le pueda servir al enemigo para avanzar o al momento de su retirada. Esta táctica sirve para que la fuerza enemiga no consiga ningún recurso, lo que le dificultará todo tipo de despliegue y mostrará a su enemigo puntos débiles que le servirán a este para el ataque.

10 Debido a que el Gobierno sirio había perdido presencia en las regiones del país y que sus acciones militares no estaban teniendo resultados positivos, el presidente Bashar al-Asad decidió utilizar armas químicas. Las primeras veces que las implementó fueron de baja intensidad y se lanzaron en las ciudades de Yaubar y Homs, así como en los barrios cercanos a la capital, como Zamalka y Arbin (ÁlvarezOssorio, 2017). No obstante, esta actividad escaló cuando el 21 de agosto de 2013 el régimen bombardeó con gas sarín la zona de Guta, a las afueras de Damasco, que permanecía bajo el control del Ejército de Liberación Siria. Este ataque dejó como saldo final la muerte 1466 personas, entre las cuales el 29\% eran nińos. 
la guerra civil siria con hipótesis superficiales. Para algunos, por ejemplo, el conflicto bélico sirio se debe a un problema de tolerancia, ya que entre chiitas y sunitas prevalece el radicalismo islámico, afirmación que no es cierta, porque, primero, no todos los actores que intervienen en la guerra profesan algún credo, pues algunos solo lo hacen por intereses económicos; $\mathrm{y}$, segundo, dentro de esas dos ramas del islam existen inmensas diferencias.

Ahora bien, para otros analistas, la confrontación armada en Siria se reduce a una rencilla entre las potencias internacionales que quieren apoderarse de los recursos naturales de aquel país, sentencia que no es completamente cierta, pues, como se mencionó al inicio de este capítulo, la importancia de Siria en términos geopolíticos está dada más por su ubicación que por sus recursos; por otra parte, las potencias tienen una agenda de intereses más holística y, por ende, su actuación está determinada por otros motivos que van más allá de lo económico.

En ese sentido, para identificar mejor los actores de la oposición al gobierno de Bashar al-Asad y sus intereses, se dividirán estos en tres grandes segmentos: 1) población civil que resistió al régimen desde la orilla de la participación democrática; 2) grupos armados civiles que nacieron de manera genuina de las manifestaciones; y 3) grupos armados islamistas radicales.

En lo que respecta a la población civil, se pueden identificar dos tipos de actores, uno con proyección internacional y otro local. El primero de estos fue el Consejo Nacional Sirio (en adelante CNS), creado en agosto de 2011 en Turquía, cuyo objetivo político consistía en ser el interlocutor del pueblo sirio con el mundo. Su planteamiento principal se centraba en la creación de un Estado democrático, pluralista y civil, en donde las libertades básicas fueran concedidas para todos los grupos poblacionales sin importar su credo. En ese sentido, solo hasta octubre de 2012 logró congregar aproximadamente el 90\% de los grupos de oposición y se convirtió en el principal canal de comunicación de la organización Amigos de Siria ${ }^{111}$. No obstante, su incapacidad para ofrecer una propuesta clara para la transición de poder de Bashar al-Asad,

11 Los países que se oponían a Bashar al-Asad se organizaron en el grupo denominado 'Amigos de Siria', el cual estuvo conformado por más de cien países y algunas organizaciones internacionales y regionales como, por ejemplo, la Organización de las Naciones Unidas, la Unión Africana, la Liga Árabe y la Unión Europea. Los Amigos de Siria tuvieron como punto de referencia al CNS, pues lo identificaban 
sumado a la pluralidad ideológica de los grupos y la presión por la disyuntiva de tomar las armas o continuar con los medios democráticos, hicieron que el CNS perdiera fuerza y legitimidad, ya que algunos grupos de oposición se retiraron.

Ante tal situación, en noviembre de 2012, se creó la Coalición Nacional para las Fuerzas de la Oposición y la Revolución Siria, unión que fue respalda por Estados Unidos y en la que fueron incluidos los miembros del CNS. Si bien el objetivo de esta organización era darle vitalidad a la oposición, su falta de unicidad, las disputas de poder y su alta dependencia internacional hicieron que la oposición se quebrara, lo que permitió a los grupos armados ganar mayor protagonismo en el conflicto armado sirio y, de manera indirecta, fortalecer al gobierno de Bashar al-Asad.

Ahora bien, el segundo actor de la población civil, pero con un énfasis provincial, fue conformado por los Comités Locales de Coordinación, cuyo interés político se centró en canalizar las inconformidades de la población siria, así como en ayudar a dar respuesta a los problemas inmediatos. En consecuencia, su estrategia se enfocó en prestar atención a los enfermos y heridos, recolectar la basura, organizar las asambleas y otros servicios sociales que fueron de vital importancia ante tal situación de caos. Los comités se caracterizaron por trabajar de manera coordinada pero no centralizada, de ahí que su oposición resultó más determinante en lo local que en lo nacional, por ello no pretendían dirigir las movilizaciones nacionales. De otra parte, a pesar de que su trabajo era in situ, no lograron escapar de la disyuntiva que planteaba realizar la oposición por medio de los canales democráticos o a través de la revuelta armada. Aunque la mayoría se mantuvo en la acción civil, algunos de los comités decidieron militarizarse, lo que terminó opacando a los primeros.

En ese sentido, la oposición civil siria no logró unificarse por sus diferencias en los métodos de lucha, lo que llevó a consolidar, de manera indirecta, a Bashar al-Asad en el poder, a radicalizar las posiciones políticas y a resolver las diferencias por medio de las armas.

como el gran 'paraguas' de la oposición, pero luego de sus dificultades internas y externas le retiraron su apoyo. 
Con relación a los grupos armados civiles que nacieron de manera genuina de las manifestaciones, el Ejército de Liberación Sirio (en adelante ELS) es su mayor exponente. Su nacimiento se da para mediados de julio de 2011, en la ciudad de Idlib. Fue conformado por soldados que decidieron desertar del Ejército del régimen debido a los ataques contra la población, así como también por civiles que, agotados por la represión del Gobierno, decidieron tomar las armas. Su principal objetivo, aparte de resistir a los ataques armados de al-Asad y buscar su derrocamiento, era construir un Estado democrático que le garantizara la plena igualdad de derechos a todos los ciudadanos. Por esta razón, y por la protección a los civiles, es que al comienzo de la guerra civil interna el ELS tenía comunicaciones con el CNS, al punto de que muchos consideraban al primero como el brazo armado del segundo. No obstante, en la medida en que el conflicto se recrudecía y se degeneraba, el ELS terminó, en algunas ocasiones, siendo respaldado por Turquía y trabajando de manera conjunta con Al-Nusra. Este deterioro de la guerra civil, junto con el ingreso de facciones islámicas radicales, hizo que el ELS perdiera su rumbo.

En la última clasificación de la oposición a Bashar se encuentran los grupos radicales islamistas, organizaciones que se caracterizaron por no solo querer derrocar al gobierno sirio, sino también, por perseguir la instauración de un gobierno islamista. A pesar de que durante la guerra se han presentado varias organizaciones con estas características, en esta sección solo se ahondará en el Estado Islámico (en adelante EI), el Frente Al-Nusra y el Frente Sirio de Liberación Islámica, ya que fueron estos los que jugaron un mayor protagonismo en los combates y tuvieron mayor presencia en el territorio sirio.

El EI, también conocido como Dáesh, es una propuesta política, religiosa y militar que nace en Irak en 2003. A pesar de que en sus orígenes su lucha estaba limitada en lo nacional, la incursión militar de Estados Unidos en la región — con las guerras de Afganistán (2002) y de Irak (2003), que trajeron como consecuencia la expansión de la influencia iraní en la región para contrarrestar la presencia de Washington- hizo que el EI internacionalizara su lucha. Esto llevó al EI a reforzar su discurso estratégico del 'doble enemigo', que corresponde al lejano (Estados Unidos) y al próximo (los chiíes representados en Irán $)^{12}$.

12 Es importante aclarar que existen dos diferencias sustanciales entre el EI y Al-Qaeda. La primera de estas hace referencia a la identificación de los enemigos, y la segunda a la determinación del 
La guerra civil siria también se convirtió en una inmensa oportunidad para el accionar y el reforzamiento del discurso ideológico del EI, ya que, de acuerdo con la profecía de Mahoma, sería la Gran Siria el lugar donde se llevaría a cabo la batalla final de los tiempos. Es por esta razón que el EI aplicó una estrategia sin precedentes, al punto de ser capaz de organizar campañas militares e institucionales, con el fin de asemejarse a la estructura de un Estado. El EI logró tener el monopolio de la fuerza en un 50\% del territorio sirio y otra parte considerable en Irak, un gobierno central, una capacidad para cobrar impuestos, un sistema judicial y un cuerpo de seguridad robusto.

Así pues, el EI logró su máxima capacidad de acción en $2015^{13}$, pero la intervención de Rusia y los bombardeos que realizó hicieron que de manera progresiva el EI iniciara su declive, motivo por el cual la violencia se recrudeció en los años siguientes, siendo el 2016 y el 2017 los años que más dejaron muertos por ataques terroristas. Como se evidencia en la figura 2 , mientras que para el 2015 el EI controlaba $90.800 \mathrm{~km}^{2}$ y había asesinado a 6141 personas; luego del ingreso de Rusia en la guerra, en 2016 , el EI perdió $12.800 \mathrm{~km}^{2}$, pero aumentó la muerte de civiles, llegando a 9150 víctimas, cifras que evidencian el punto máximo de la guerra. Para 2017, el EI redujo su presencia territorial, pues controlaba $60.400 \mathrm{~km}^{2}$, y los asesinatos cayeron a 4350, muestra de que los golpes propiciados por Rusia habían sido efectivos y de que el EI estaba perdiendo acción en Siria.

Para finales de 2017, como resultado de los ataques del Ejército kurdo, respaldado por los bombardeos estadounidenses, y la respuesta militar rusa como respaldo al gobierno de Bashar al-Asad, el EI se redujo a su máxima expresión y se desplazó hacia Irak.

momento para declarar el califato. Con respecto a la primera, mientras que Al-Qaeda considera no incluir a todos los chiíes como sus enemigos, para el EI sí deben incluirse todos, incluso a los suníes que no les obedezcan. Con relación a la segunda, para Al-Qaeda la guerra se debe declarar primero al enemigo lejano, mientras que para el EI el primero a derrotar es el enemigo próximo (De Currea-Lugo, 2019).

13 De acuerdo con el reportaje realizado por Clara Roig para el medio de comunicación español La Vanguardia, en 2015, el EI logró amasar 81 millones de dólares provenientes del cobro de impuestos, extorsiones, venta de petróleo y de obras de arte. No obstante, el ingreso de Rusia a la guerra civil y los ataques contundentes del Ejército kurdo, respaldado por Estados Unidos, hicieron que el EI perdiera su capacidad económica. De ahí que, para 2016, la organización terrorista reuniera tan solo 16 millones de dólares, es decir, su pérdida económica de un año a otro fue del 80,25\% (Roig, 2017). 


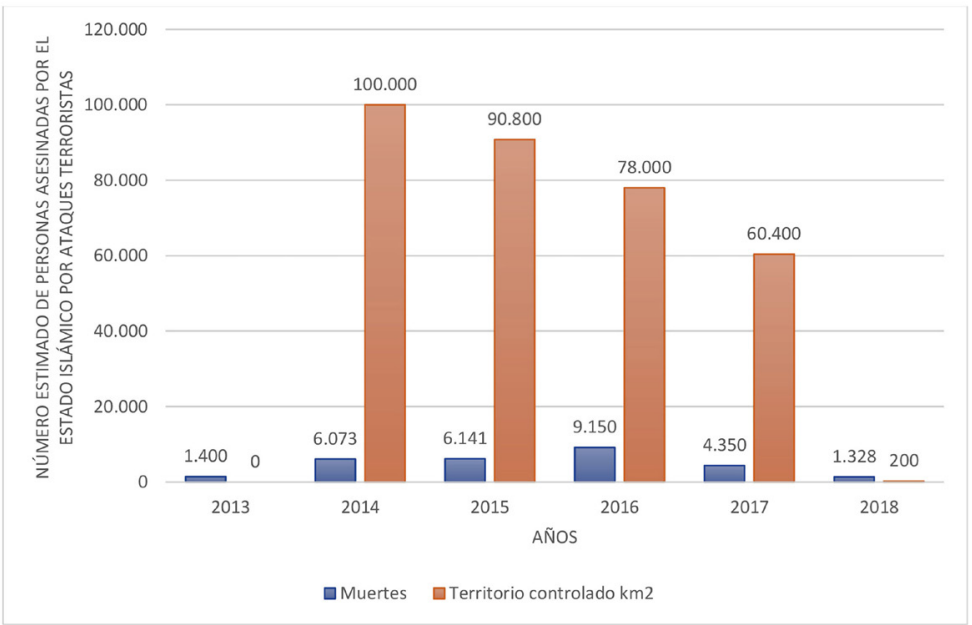

Figura 2. Ascenso y caída del EI

Fuente: McCarthy (2019)

No obstante, y a pesar de que las víctimas civiles se redujeron, como se observa en la figura 2, en 2017 la guerra civil siria seguía siendo el conflicto armado que dejaba más víctimas por armas explosivas en ese año, como se evidencia en la figura 3.

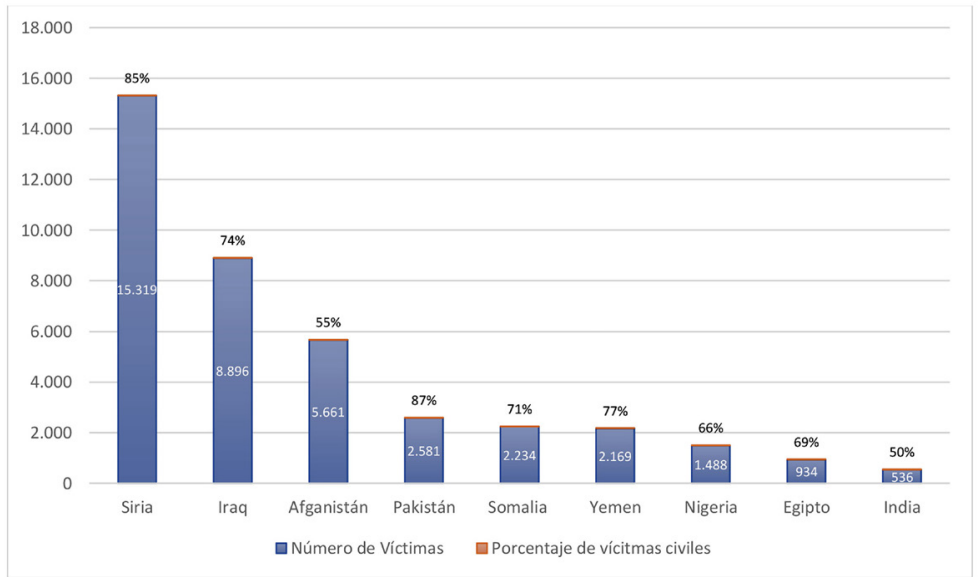

Figura 3. Víctimas de violencia Fuente: McCarthy (2018) 
En cuanto al Frente Al-Nusra, esta organización nace en enero de 2012 y sus orígenes se remiten, exclusivamente, al contexto de la guerra civil siria. Sus objetivos políticos no siempre fueron claros, pues si bien buscaban derrocar a Bashar al-Asad e instaurar un gobierno islámico, se vieron inmersos en las contradicciones propias de las organizaciones islámicas ${ }^{14}$, lo que les dificultó tener una claridad en sus proyecciones. En consecuencia, esta organización terrorista tuvo que reorganizarse en 2016 y cambió su nombre al de Organización para la Liberación del Levante. Este grupo terrorista, si bien tuvo una corta vida, es relevante en el conflicto sirio, ya que en sus orígenes fue el brazo de Al-Qaeda dentro del conflicto bélico sirio y también intentó trabajar de manera conjunta con el EI.

Por último, el Frente Sirio de Liberación Islámica (en adelante FSLI) fue una coalición, conformada por 20 grupos religiosos, que nace en diciembre de 2012, lo que la llevó a ser considerada como la segunda oposición más fuerte, ya que logró tener presencia en ciudades importantes de Siria como, por ejemplo, Damasco, Alejo, Homs, Idlib, entre otras. Su principal financiación provino de países de la región como Arabia Saudita, Qatar y Kuwait, y sus objetivos políticos estaban encaminados a reducir la importancia del EI, derrocar a Basahr e instaurar un gobierno islámico. En ese sentido, el FSLI logró tener una buena relación con el ELS, porque compartían las dos primeras metas, pero tenían diferencias con respecto al tercer punto, pues mientras que el FSLI era más radical con respecto a instaurar un gobierno islámico, el ELS solo deseaba construir un Estado laico.

Debido a sus diferencias internas con respecto a la relación de otras facciones islámicas — como los Alawí- y su negación a la injerencia internacional, en noviembre de 2013, siete grupos, entre ellos los tres más grandes, decidieron crear el Frente Islámico. No obstante, este último también entró en crisis meses después, porque surgieron diferencias internas por la manera como

14 De acuerdo con Víctor De Currea-Lugo (2019), las contradicciones comunes entre las organizaciones islámicas se pueden centrar en: 1) discordancia en las propuestas nacionalistas; 2) ambigüedad respecto a las propuestas globales islamistas (eliminar primero al enemigo próximo o al lejano); 3) interpretaciones radicales del Corán y su relación con la población con sus respectivas creencias confesionales; 4) búsqueda de apoyos regionales (Arabia Saudita y Qatar); y 5) aprobación o desaprobación de asesinatos de la población civil. 
se debería responder frente al EI, pues, mientras que algunos atacaban directamente al EI — porque lo consideraban una influencia extranjera-, otros los apoyaban o luchaban de la mano con él.

\section{Participación de las potencias de la ordenanza mundial}

En la guerra civil siria, las potencias de la ordenanza mundial también jugaron un papel fundamental, no solo por su participación militar, sino también, en razón de sus propias agendas e intereses políticos y económicos, que se convirtieron en factores relevantes para que la paz en Siria aún no llegue a un feliz término. Las dos potencias de la ordenanza mundial que tuvieron injerencia en el conflicto bélico fueron Estados Unidos, con sus respectivos aliados (Israel y Arabia Saudita), y Rusia, que respaldó de manera directa a Bashar al-Asad.

\section{Estados Unidos}

Estados Unidos ha sido un actor de bastante controversia en la región debido a los daños que ha causado con sus guerras en países como Afganistán e Irak. El objetivo político de Washington en la guerra civil siria era derrocar a Bashar al-Asad y, a partir de este hecho, crear una nueva oportunidad para recuperar su influencia en esta zona, la cual ha perdido de manera progresiva desde la Revolución islámica de Irán, llevada a cabo en 1979.

Durante el siglo XXI, las actuaciones de Estados Unidos en Oriente Próximo se explican a partir de la postura del ala política neoconservadora que ha reinado desde el gobierno de George W. Bush (2001-2009). Esta considera, por un lado, que la política exterior de Washington es el instrumento mediante el cual se puede influir en la naturaleza de los Estados y su ordenamiento institucional, y, por otro, que sus acciones están justificadas a partir de razonamientos morales (Haass, 2009). Es por ello que, con base en este enfoque político, Estados Unidos ha estructurado sus guerras en Oriente Próximo, luego de los atentados del 11 de septiembre de 2001.

No obstante, los resultados de estas intervenciones militares en la región han sido perjudiciales para los propios estadounidenses ya que, como lo mencionan Stiglitz y Bilmes (2008), solo la guerra de Irak le costó al erario unos 3000 millones de dólares, a lo que debe sumarse el incremento del rechazo por 
parte del pueblo árabe hacia los Estados Unidos, lo que fortaleció las ideas radicales de los grupos islamistas y permitió que creciera la influencia iraní, ya que este país, al sentirse rodeado por bases militares norteamericanas, ha tomado una estrategia diplomática más activa en la región. Como consecuencia de lo anterior, sumado a la crisis financiera de 2009 y al resurgimiento de China como principal potencia competidora de Estados Unidos, Washington ha tenido que retirarse de manera progresiva de la región y limitar sus acciones para concentrarse en el gigante asiático.

Por tal motivo, tanto las administraciones de Barack Obama (20092017) como la del presidente Donald Trump (2017-2021) han aplicado una limitada estrategia para esta zona, la cual está compuesta por tres elementos: 1) transferir responsabilidades a sus aliados regionales que, en el caso de la guerra civil siria, se materializó con que Arabia Saudita e Israel fueron los países encargados en apoyar militar y financieramente a los grupos islamistas para que derrocaran a Bashar al-Asad; 2) procurar no desplegar hombres en tierra $^{15} \mathrm{y}$, por el contrario, crear y respaldar coaliciones para que sean estas las que hagan frente en las batallas —de hecho, en la situación de Siria, Washington respaldó políticamente a la Coalición Nacional para las Fuerzas de la Oposición y la Revolución Siria y, en términos militares, desde el aire apoyó con bombardeos a las Fuerzas Democráticas Sirias, las cuales libraban las confrontaciones en tierra-; y 3) establecer o reafirmar autoridades nacionales para que a través de estas logren aliarse con líderes locales y obtener así acuerdos (Karlin \& Wittes, 2019).

No obstante, esta estrategia que fue esbozada por el General Joseph Votel, comandante del Comando Central de Estados Unidos, no ha tenido resultados positivos en la guerra siria porque sus aliados regionales y las autoridades que han creado no tienen los intereses alineados con los de Washington. A lo ante-

15 A pesar de que la idea principal es evitar el despliegue de hombres en tierra, en el caso de la guerra civil siria, Washington ordenó desembarcar 2000 hombre en suelo de este país en mayo de 2015. Barack Obama argumentó la legitimidad de esta acción con base en la "Autorización para el Uso de la Fuerza Militar" (AUMF, por sus siglas en inglés), resolución aprobada por el Congreso estadounidense el 14 de septiembre de 2001 y cuyo objetivo es contrarrestar a todos aquellos que cometan, planeen, autoricen o ayuden a realizar ataques terroristas. En consecuencia, el EI se convirtió en el principal motivo para que se realizara tal movimiento de tropas en Siria, sin necesidad de la autorización del Congreso (Mulroy \& Oehlerich, 2020). 
rior, se debe añadir la subestimación que hizo la Casa Blanca con respecto a las habilidades rusas para convertir a Siria en un trampolín para ganar influencia en la región, lo que ha dejado como ganador, hasta el momento, a Rusia, pues logró convertirse en un actor necesario para alcanzar la paz en Siria y le permitió a Bashar al-Asad permanecer en el poder.

\section{Rusia}

Como se ha mencionado antes, Rusia ingresó al conflicto bélico sirio en septiembre de 2015, cuatro meses después de que arribaran las primeras tropas estadounidenses al territorio sirio. El movimiento militar ruso, además, se da como consecuencia de la propuesta de Estados Unidos en el CSNU de aprobar una resolución para que la 'comunidad internacional' interviniera militarmente a Siria, como sucedió con Libia en 2011. Este deseo alertó a Moscú, pues, dado el caso que Bashar al-Asad fuera derrocado por Estados Unidos, esto le permitiría al país norteamericano imponer un gobierno más inclinado hacia Washington y tener presencia militar en ese territorio, lo que significaría tener más influencia en la región y afectaría la seguridad rusa por la posición geográfica que tiene Siria.

Los objetivos políticos de Rusia eran mantener a Bashar al-Asad en el poder, comportarse frente a Estados Unidos como una gran potencia y controlar las ambiciones unilaterales de Washington. Con el fin de lograr estas pretensiones, Putin continuó aplicando la doctrina 'Primakov', conjunto de ideas creadas por el ex primer ministro Yevgeny Primakov (1996-1998) que apuntan a ver la unipolaridad de Estados Unidos en el mundo como una situación inaceptable. En consecuencia, Primakov constituye tres tareas rectoras de la política exterior rusa, a saber: 1) Rusia debe esforzarse por configurar un mundo multipolar que esté administrado por un concierto de grandes potencias que logren contrabalancear a Washington; 2) Moscú deberá insistir sobre su primacía en el espacio postsoviético y liderar una integración en esa región; y 3) Rusia deberá oponerse a la ampliación de la Organización del Tratado del Atlántico del Norte (OTAN) (Rumer, 2019).

La claridad de las pautas de la doctrina Primakov, además de la voluntad y la buena aplicación de un poder inteligente ${ }^{16}$ por parte de Putin, han ubicado

16 El poder inteligente (smart power) es un concepto creado por Joseph Nye en 2003 que hace referencia a la combinación y aplicación adecuada y precisa de las herramientas blandas y duras para 
a Rusia como uno de los principales ganadores en la guerra civil siria, pues: 1) mantuvo en el poder al presidente Bashar al-Asad; 2) a pesar de tener claro que sus recursos económicos y militares eran limitados, logró reestablecerse por sí sola en una potencia política clave para la región y; 3) no solo redujo las pretensiones de Estados Unidos en Oriente Próximo sino que, además, obtuvo una base aérea alrededor de Damasco y fortaleció su punto estratégico en aguas tibias del Mediterráneo, con su instalación naval ubicada en la ciudad de Tartus, Siria.

Ahora bien, aunque es cierto que Rusia ha sido, hasta ahora, uno de los principales ganadores de la guerra siria, el conflicto armado sirio no ha terminado a pesar de que su intensidad se ha reducido. En ese sentido, Rusia se enfrenta hoy a dos preguntas clave para continuar con su estrategia: 1) habiendo logrado esta ventaja y posicionamiento en Oriente Próximo, ¿el Kremlin debería tomar riesgos adicionales para lograr sus ambiciones y aspiraciones globales, incluso si eso representase el divorcio con la doctrina Primakov?; o 2) por el contrario, ¿debería continuar aplicando la doctrina Primakov con un cuidadoso análisis de costos y beneficios de cada una de las acciones que emprenda?

\section{Naturaleza del conflicto}

Durante los últimos años, se ha desarrollado un debate en torno al carácter de las 'nuevas guerras' ${ }^{17}$; no obstante, a pesar de las diferencias existentes para identificar la naturaleza y las causas de los nuevos conflictos armados, hay tres evidencias empíricas que permiten llegar a un consenso sobre el cambio en los patrones de la violencia en el siglo XXI (Mello, 2010), estas serían: 1) la constatación de un drástico aumento en las tasas de civiles muertos en compa-

producir efectos positivos en la política exterior de un país. De acuerdo con Nye, hay tres caminos básicos para lograr que un Estado influya en otro: coerción, pago y atracción. En el poder duro se clasifican lo que son la coerción y el pago, mientras que en el blando se ubica la atracción (Nye, 2009).

17 Las nuevas guerras se clasifican como 'guerras de la globalización', pues se desarrollan en áreas donde los Estados autoritarios se han debilitado como consecuencia de la apertura al mundo. De igual manera, surgen a raíz de la evaporación de las líneas entre lo público y lo privado, lo estatal y lo no estatal, lo interno y lo externo, lo político y lo económico, la paz y la guerra. En ese sentido, el rompimiento de las anteriores combinaciones binarias es lo que permite comprender las causas y las consecuencias de las nuevas guerras. 
ración con los decesos militares, pues, de acuerdo con Chesterman (2001), los fallecimientos de civiles durante la Primera Guerra Mundial ascendieron al 5\% del total de muertos, para la Segunda Guerra Mundial aumentó al 50\%,y para los años novena se incrementó hasta el 90\%; 2) esta tendencia coincide, a su vez, con la multiplicación del número de guerras civiles de larga duración, pues, de acuerdo con Mello (2010), desde la mitad del siglo XX el número de guerras catalogadas como 'infranacionales' ha sido ocho veces mayor que el de las guerras entre Estados; y 3) la distribución de las guerras de esta índole se concentran en África Subsahariana, Asia central, el subcontinente indio y el sudeste asiático.

Ahora bien, con base en los criterios de actores, objetivos, métodos y financiamiento, establecidos por Mary Kaldor (2013), la guerra civil siria se puede clasificar en la lógica de las 'nuevas guerras' por cuatro razones que se desglosan a continuación.

Primero, porque los actores que intervienen en el conflicto armado son un conjunto de agentes conformados no solo por Estados, sino también por fuerzas irregulares, compañías de seguridad privada y mercenarios, entre otros. Por otra parte, el involucramiento de todos estos actores se debe a que el Estado, debido a la globalización, ha perdido el monopolio legítimo del uso de la fuerza (Mello, 2010), ha disipado su capacidad política para decidir qué hacer y su cualidad económica para actuar en la sociedad (Bauman \& Bordoni, 2016). Como consecuencia del desmantelamiento del Estado, se produce un efecto en espiral, pues una vez las autoridades legítimas que ostentan el monopolio del uso de la fuerza pierden esta prerrogativa, la violencia privada aparece (Brozoska, 2004), como se evidenció en el régimen de Bashar al-Asad y en las dinámicas de la guerra civil siria.

Segundo, los objetivos en los enfrentamientos del siglo XXI cambian, pues, mientras que en las viejas guerras se luchaba por intereses ideológicos, en las nuevas guerras los combatientes se enfrentan a nombre de la política de la identidad (Kaldor, 2013). Esta última se caracteriza porque los grupos enfrentados no luchan para llegar al Estado a imponer una política o un programa particular que apunta al interés general del público, por el contrario, los grupos buscan acceder al Estado para beneficiarse de manera particular. También es 
importante resaltar, que cuando se habla de 'identidad' no se hace referencia únicamente a temas culturales, dicho término también incluye los factores políticos y económicos que, en muchas ocasiones, son los incentivos reales del conflicto armado (Mello, 2010), como se demostró con el EI.

Tercero, los métodos y las tácticas de las nuevas guerras se caracterizan por materializarse en conflictos armados irregulares o asimétricos (Kaldor, 2013; Badie \& Vidal, 2016). La estrategia del contrincante es buscar desajustar lo político y económico tanto a nivel interno como externo, mientras que con su táctica trata de generar dislocaciones de tropas en diferentes partes del territorio para que realicen ataques rápidos, pero sin que eso garantice el fin de la guerra, pues lo que buscan no es ganar el conflicto bélico, al contrario, lo que intentan es perpetuarlo y desgastar a su enemigo, porque la guerra en sí misma es un beneficio para los grupos armados irregulares (Brozoska, 2004; David, 2013; Mello, 2010). De igual manera, las organizaciones armadas que desafían al Estado, al tener una desventaja militar y económica con respecto a este, se apoyan en la violencia simbólica o la propaganda para ganar adeptos en la población y algunos recursos financieros. En este criterio también se ubican los ataques terroristas, que son utilizados por todos los actores y buscan generar terror en la población civil cuando se encuentran en una situación de dificultad o de debilidad. Los anteriores comportamientos se evidenciaron, por ejemplo, con la maquinaria propagandista del EI y los ataques indiscriminados a la población no combatiente por parte de este grupo terrorista y del Estado sirio.

Cuarto, a diferencia de las guerras viejas, en las nuevas guerras el financiamiento no proviene exclusivamente del Estado, sino que, también, debido a la globalización, han surgido nuevos mecanismos para que los actores obtengan mayores recursos económicos para lograr sus objetivos militares. Cabe resaltar que, como menciona Mary Kaldor (citado por Mello, 2010), la economía de las nuevas guerras tiende a perpetuar ciclos de violencia y el comportamiento criminal, pues en las actuales guerras los agentes necesitan reproducir el conflicto para mantener el poder y los recursos obtenidos durante los enfrentamientos. Un ejemplo de lo anterior son las compañías militares de seguridad privada, las cuales requieren que existan conflictos armados — como la guerra civil siria - para que los Estados los contraten y así poder prestar sus servicios. 
En el caso del conflicto armado sirio, los grupos terroristas que enfrentaban a Bashar al-Asad se financiaron gracias a recursos provenientes de países de la región, pero también de negociar arte, de la venta de petróleo con destino a Europa o del lavado de dinero.

Una vez explicados los principales hitos, los actores y sus intereses, así como la naturaleza de la guerra civil siria, en la parte dos de este capítulo se estudiará el rol que ha jugado la Organización de las Naciones Unidas, junto con sus organismos subsidiaros, en el conflicto armado ya mencionado.

\section{Rol de las Naciones Unidas en la guerra civil siria}

Como se evidenció anteriormente, la naturaleza de la guerra civil siria está en el marco del cambio general de la tendencia de la violencia en el siglo XXI, transformación que demuestra, además, importantes desajustes en el sistema de seguridad colectiva, el cual está construido con base en las relaciones interestatales y el concepto de soberanía como un atributo inherente al Estado.

En estos nuevos contextos de guerras se evidencia, con mayor claridad, la incapacidad para que las organizaciones internacionales, como la Organización de las Naciones Unidas y sus órganos subsidiarios, logren ofrecer respuestas y soluciones adecuadas y oportunas para la resolución de los conflictos bélicos y proteger a la población de estos, a pesar de tener los capítulos VI y VII para solventar tales controversias. Ante la parálisis del CSNU por los intereses geopolíticos de los Estados miembros, que han llevado a que la ONU no pueda cumplir su misión de "preservar a las generaciones venideras del flagelo de la guerra que dos veces durante nuestra vida ha infligido a la Humanidad sufrimientos indecibles" (Naciones Unidas, 1945), desde el 2001 ha surgido el principio de 'proteger ${ }^{18}$, que busca suplir algunas deficiencias del sistema de seguridad colectiva (Cebada, 2017).

18 El principio de 'proteger' se basa en dos razonamientos esenciales. El primero apunta a que la soberanía de un Estado conlleva a esta unidad política a tener responsabilidades, por lo tanto, le incumbe actuar para proteger a la población. El segundo hace referencia a que el Estado actuará cuando la población esté sufriendo graves daños como resultado de una guerra civil, una insurrección, la represión ejercida por el mismo Estado o el colapso de sus estructuras (International Commission on Intervention and State Sovereignty, 2001). 
De conformidad con lo anterior, en el "Informe 2001 sobre la Responsabilidad de Proteger”, elaborado por la Comisión Internacional sobre Intervención y Soberanía de los Estados, se estructuran tres responsabilidades específicas, a saber: 1) responsabilidad de prevenir; 2) responsabilidad de reaccionar; y 3) responsabilidad de reconstruir (International Commission on Intervention and State Sovereignty, 2001). No obstante, es hasta el 2005 que la responsabilidad de proteger fue refrendada por los diferentes órganos de la Naciones Unidas, pero con la claridad que los Estados deberán agotar todas las opciones antes de contemplar la posibilidad de intervenir. De igual manera, el CSNU será la principal autoridad para aprobar una intervención militar con fines de protección humana, en consecuencia, las potencias deberán renunciar, de mutuo acuerdo, a ejercer su derecho de veto para no obstaculizar la aprobación de las resoluciones. No obstante, dado el caso de que el CSNU rechace la propuesta o no la tramite en el tiempo estipulado, será la Asamblea General (en adelante AG) la encargada de examinar la cuestión con arreglo al procedimiento establecido en la resolución "Unión pro-Paz" o, en su defecto, será una organización regional la que, en virtud del Capítulo VIII de la Carta, podrá actuar dentro de su zona de jurisdicción para, posteriormente, solicitar la autorización al CSNU.

Con base en el desarrollo jurídico internacional antes mencionado, la primera vez que se utilizó el principio de proteger fue en el caso le Libia, con la Resolución 1973 de marzo de 2011, como se explica en el segundo capítulo de este libro. En esa ocasión, el CSNU adoptó esta medida con la abstención de China y Rusia, ya que, como posteriormente se ratificaría, la intervención militar en ese país por parte de Estados Unidos y la OTAN fue más allá de lo que permitía la resolución (Sáenz, 2012; Cebada, 2017), debido a que la coalición buscaba un cambio de régimen, acción que está en contravía del principio de la no intervención en los asuntos internos. Como consecuencia de lo anterior, Libia lleva nueve años viviendo un caos militar y político, sin una pronta solución al problema y siendo un foco de desestabilización para la región y la seguridad colectiva.

Como consecuencia de los malos resultados de la aplicación del principio de 'proteger' en Libia, cuando Estados Unidos en el CSNU propuso aplicar 
este en la guerra civil siria, Rusia y China se opusieron, utilizando su veto por dos motivos: primero, identificaron que Washington, más que proteger a la población civil, buscaba cambiar el régimen, por lo que nuevamente estaría en contra del principio de la no intervención en los asuntos internos, y, segundo, tanto Moscú como Beijing querían evitar un desafortunado desenlace, como el que sufrió Trípoli. Así pues, la situación de Libia permite entender la actitud de Rusia y China con respecto a la guerra civil siria y las razones por las cuales este mecanismo internacional no tuvo cabida en el conflicto armado analizado en este capítulo.

La parálisis del CSNU por los intereses geopolíticos de los Estados miembros, como se evidenció en el caso del principio de 'proteger', se materializó cuando este órgano de las Naciones Unidas, debido al veto de Rusia y China, no remitió a la Corte Penal Internacional la situación de los crímenes de lesa humanidad y los crímenes de guerra ${ }^{19}$ que se estaban cometiendo en Siria durante sus nueve años de conflicto armado. Ahora bien, mientras que algunos mecanismos para frenar el flagelo de la guerra siria no se han podido aplicar por falta de voluntad política, la crisis humanitaria en ese país sigue presente.

Es así que el conflicto armado sirio demostró y agudizó el debate internacional que gira alrededor de cuatro temas: 1) la dificultad para aplicar el principio de 'proteger' en zonas de mucho interés geopolítico, y el inconveniente para eliminar la desconfianza de los Estados para que este mecanismo no sea utilizado con fines políticos de injerencia en asuntos internos; 2) la necesidad de compartir las cargas económicas de los refugiados; 3) el papel de las agencias humanitarias y de la gobernanza global para brindar respuestas a las víctimas durante los procesos de negociación entre los actores; y 4) la aplicación de las

19 Los crímenes de lesa humanidad y de guerra hacen parte del concepto de 'crímenes internacionales', que se refiere a actos que, por su gravedad, implican una responsabilidad penal internacional a los individuos que los cometieron. Los crímenes de lesa humanidad son once conductas que una organización o un Estado comete de manera sistemática o generalizada contra una población civil. Los actos de esta categoría son: asesinato, exterminio, esclavitud, deportación o traslado forzoso de población, privación arbitraria de la libertad, delitos sexuales, persecución, tortura, desaparición forzada, entre otros actos inhumanos que tengan el mismo carácter. El concepto 'crímenes de guerra' corresponde a la clasificación más antigua y comprende todas aquellas conductas que atentan contra personas que no participan o que han dejado de participar en las hostilidades, contra bienes no militares o con métodos de combate o armas que, por su esencia, causan daños indiscriminados; en esta categoría se ubican más de cincuenta conductas (Salazar, 2019). 
mismas estrategias erróneas por parte de las Naciones Unidas para crear las posibles soluciones que, en su mayoría de veces, provienen de las élites políticas que están en discordancia con las necesidades de la población civil.

Ahora, con el fin de comprender de manera más detallada el papel que ha jugado la ONU y sus órganos subsidiarios en la guerra civil siria, a continuación, se explicarán las diferentes resoluciones y acciones que realizaron el CSNU, la AG y el Consejo de Derechos Humanos con relación al conflicto armado sirio.

\section{Consejo de Seguridad de las Naciones Unidas}

De acuerdo con la Carta de Naciones Unidas en el capítulo V en su artículo 24, el CSNU es el órgano responsable de "mantener la paz y la seguridad internacionales" y, en consecuencia, dota al Consejo de herramientas para que pueda lograr su objetivo principal. Es así como, en el capítulo VII en el artículo 39 le otorga al CSNU la capacidad para determinar la existencia de toda amenaza a la paz, quebramientos de la paz o actos de agresión, como un paso previo a la adopción de medidas coercitivas, incluso armadas si el caso lo amerita, disposiciones que están consignadas en los artículos 41 y 42 .

Aun cuando el CSNU está dotado con los instrumentos necesarios para que la humanidad no vuelva a sufrir los flagelos de la guerra, los intereses geopolíticos de los Estados miembros permanentes siguen anteponiéndose a los objetivos principales de la ONU, lo que hace que este órgano actúe de manera tardía frente a los problemas de seguridad internacional. Ejemplo de esto es la guerra civil siria, pues, debido a la desconfianza de Rusia y China hacia las intenciones de Estados Unidos y sus aliados en la región, se opusieron en reiteradas ocasiones a la adopción de resoluciones para que el conflicto armado cesara, como también al empleo de la responsabilidad de proteger, como se explicó anteriormente.

Para la guerra civil siria, el CSNU ha emitido, de 2012 a 2020, diecisiete resoluciones, todas ellas han sido resultado de varias discusiones y arduos debates entre los países miembros. El 27 de abril de 2011 fue la primera vez que este órgano se reunió con el objetivo de hacer un primer balance sobre la situación, cita que comprobó la división entre sus miembros, ya que, 
mientras que el Reino Unido presionaba para actuar, Rusia sostenía que era un asunto interno de aquel país. El 25 de mayo de ese mismo año, Francia, Alemania, Portugal y Reino Unido presentaron un borrador de resolución en la que se condenaba la situación y se expresaba, de manera tácita, la obligación que el gobierno sirio tenía de proteger a sus ciudadanos. No obstante, para esta ocasión, Rusia, China, Brasil, India y Sudáfrica rechazaron la proposición debido a que la resolución apuntaba a determinar la naturaleza del programa de reformas del gobierno sirio y, en ese sentido, estaba direccionado a una cuestión interna que los propios sirios debían solucionar y no el CSNU. Fue en esta reunión que Moscú y Beijing le recordaron a Washington las consecuencias que tuvo la resolución 1973 de 2011 para el caso de Libia.

El 4 de octubre de 2011, los países partidarios de adoptar una resolución lo más pronto posible presentaron una nueva proposición, pero en esta ocasión pedían el fin de la violencia, introducción de algunas reformas y permitir la opción de establecer sanciones para Siria en el caso que no cumpliera tales propuestas. Ante una nueva negativa por parte de Brasil, India, Líbano y Sudáfrica, que se abstuvieron y dos votos en contra de China y Rusia, la Liga Árabe decide jugar un papel más protagónico, motivo por el cual, el 16 de noviembre, presenta una propuesta de seis puntos que, además, fueron respaldados por el Enviado Especial Conjunto de las Naciones Unidas.

De este modo, el 12 de abril de 2012, el CSNU aprobó la primera resolución (S/RES/2042) con la que autoriza el despliegue de treinta observadores militares en Siria, reafirma el apoyo al Enviado Especial Conjunto de las Naciones Unidas y la Liga de los Estados Árabes, y respalda la propuesta de los seis puntos presentados por estos dos últimos. Una vez aplicada esta resolución, el CSNU asienta la Resolución 2043 con la que soporta de nuevo la propuesta de los seis puntos y decide establecer la Misión de Supervisión de las Naciones Unidas en Siria (Unsmis), formada por un equipo de 300 observadores militares no armados, así como también por un componente civil. Para julio de ese mismo año se aprueba la Resolución 2059, con la que prorrogaba el mandato de la Misión por un último periodo de treinta días más. Tres acciones que se caracterizaron por no estar basadas en el Capítulo VII de la Carta.

Un año y dos meses después, el 27 de septiembre de 2013, el CSNU emite la Resolución 2118, con la que expresaba con bastante convicción que 
las personas responsables del empleo de armas químicas debían rendir cuentas por sus actos; no obstante, este documento fue tímido, pues, a pesar de que en el informe 13 de la Misión de Expertos de Naciones Unidas que se envió a Siria mencionaba que el Gobierno Sirio era el que utilizaba este tipo de armas, la resolución no señala al régimen de Basahr al-Asad de manera directa, dado que, de haberlo hecho, países como Rusia y China no hubieran aprobado la providencia (Gutiérrez, 2015). Para el 22 de febrero de 2014 el CSNU expide la Resolución 2139, que condena la violación de los DD. HH. y del DIH, cometidos tanto por el Gobierno como por los grupos armados; además, le exige al régimen sirio permitir el ingreso de ayuda humanitaria a las zonas más afligidas por el conflicto armado.

La resolución 2170 del 15 de agosto de 2014 es relevante, en la medida en que por primera vez el CSNU actúa en virtud del Capítulo VII de la Carta, lo que le permite, a su vez, recordarle a las naciones el cumplimiento tácito de la resolución 1373 de 2001, que obliga a todos los Estados a combatir el terrorismo, incluso localizando y haciendo comparecer ante la justicia a las personas, grupos, empresas y entidades — como Al-Qaeda, el EI y el Frente Al-Nusra- que perpetren, organicen y patrocinen esos actos de terrorismo. Se debe resaltar, de igual manera, que una vez el CSNU rechaza las actuaciones de las organizaciones terroristas con las resoluciones antes mencionadas, la Resolución 2249 de 2015 refuerza la visión de la acción unilateral para la lucha global contra el terrorismo, lo que amplía el principio de legítima defensa y la acción de los Estados para enfrentar este fenómeno, respetando los derechos humanos y el DIH.

En efecto, como se evidencia en el anexo 1, las diferentes resoluciones que el CSNU ha emitido, distintas a las que se han mencionado, y las doce sanciones adoptadas (como se muestra en el anexo 2), se han limitado a rechazar las actuaciones de los grupos armados, a renovar en tiempo el cruce de las líneas fronterizas y de fuego para el ingreso de la ayuda humanitaria, y a permitir, en ocasiones, la presencia de observadores de las Naciones Unidas en el terreno, pero ninguna de estas decisiones logra sentar las bases para la construcción de la paz en Siria. La guerra civil siria hizo evidente la falta de correspondencia entre la estructura del CSNU, el cumplimiento del objetivo de prevenir el sufri- 
miento por la guerra y las nuevas dinámicas de la vida internacional, lo que ha traído como consecuencia el surgimiento de nuevas potencias emergentes que buscan un sistema internacional más democrático. Por consiguiente, es necesario traer a colación la urgencia de hacer efectiva una reforma al CSNU, propuesta que se ha planteado desde hace ya algunas décadas atrás.

La proposición de modificar este órgano de las Naciones Unidas apunta hacia dos direcciones. La primera, con relación a la ampliación del número de sus miembros, esto, con el fin de propiciar una representación más equitativa y ajustada a las nuevas dinámicas de la vida internacional. La segunda, relacionada con los métodos de trabajo del CSNU, tiene el objetivo de aumentar la transparencia y evitar los bloqueos por los vetos. Ahora, si bien en cierto que lograr este escenario de discusión política internacional tomará más años, lo cierto es que la guerra civil siria también logró, de manera positiva, dar luces sobre algunos caminos que otros órganos de las Naciones Unidas pueden tomar en caso de un conflicto bélico. Ese es el caso de la Asamblea General, que a continuación se analizará.

\section{Asamblea General (AG) de las Naciones Unidas}

Ante el bloqueo interno del CSNU, que no llegó a ofrecer una pronta solución a la guerra civil siria, la AG de las Naciones Unidas jugó un papel más protagónico. Su proactividad en este caso se dio gracias a la Resolución 377 (v) de 1950, también conocida como "Unidos por la Paz", en la que la AG, sujeta al artículo 14 de la Carta de Naciones Unidas, asume la responsabilidad subsidiaria de mantener la paz y la seguridad internacionales dado el caso de que el CSNU, por falta de unanimidad entre sus miembros permanentes, dejase de cumplir con su responsabilidad primordial. De igual manera, en la Resolución 60/280 de 2006, se reafirma el papel de la AG como una autoridad para tener incidencia en temas relacionados con la paz y la seguridad internacionales, pero sin dejar de reconocer al CSNU como el órgano de máxima responsabilidad para resolver estos asuntos (Cebada, 2017).

De acuerdo con lo anterior, la AG jugó un papel relevante y, en lo que va corrido del inicio de la guerra civil siria, de 2011 hasta el primer semestre de 2020, este órgano plenario ha aprobado ocho resoluciones. La primera de 
ellas fue la A/RES/66/176, adoptada el 19 de diciembre de 2011, en la que se aborda la situación de derechos humanos en Siria, se condenan los hechos de violencia en ese país y se hace un llamado para que el secretario general preste su pleno apoyo a la misión de observadores de la Liga Árabe, además, se plantea la necesidad de implementar los seis puntos presentados en noviembre por esta organización regional. Para febrero 16 de 2012, bajo la A/RES/66/253, la AG refuerza su respaldo para una transición política en Siria con ayuda del Grupo de los Estados Árabes y con pleno apoyo de todos los órganos subsidiarios de las Naciones Unidas.

De esta manera, la AG logró acoplar su sinergia con la de la Liga Árabe, no solo con la A/RES/66/176 y la A/RES/66/253 A, sino también, con la Resolución A/RES/66/253 B del 3 de agosto de 2012, con la que se reafirma el papel de las organizaciones regionales y subregionales en el mantenimiento de la paz y la seguridad internacionales, y se acogen con beneplácito las decisiones pertinentes tomadas por la Liga Árabe. De igual manera, a diferencia del CSNU, el 21 de diciembre de 2016, bajo la A/RES/71/248, la AG decidió tomar un papel más proactivo y osado al crear un 'Mecanismo Internacional, Imparcial e Independiente' con el fin de asistir en la investigación y enjuiciamiento de los responsables de los crímenes internacionales y los más graves cometidos desde marzo de 2011.

Este mecanismo resulta interesante en la medida en que — así como la AG trabaja de la mano con la Liga Árabe- lo que busca es trabajar de manera conjunta con la Comisión Internacional Independiente de Investigación, creada por el Consejo de Derechos Humanos (Cebada, 2017). Así, a diferencia del trabajo de la Comisión, que elabora informes y realiza las investigaciones, el Mecanismo prepara, bajo el principio de la confidencialidad, el sumario y las pruebas que permitirán en el futuro enjuiciar a los presuntos culpables. La estrategia implementada por la AG para trabajar de la mano con la Liga Árabe y el Consejo de Derechos Humanos, si bien fue una solución a la inacción del CSNU para el caso de Siria, se puede catalogar como una innovación que podría, en un futuro, oxigenar el sistema de seguridad colectiva y el mismo derecho internacional penal. 
Para que el lector pueda profundizar más sobre las acciones de la AG, en el anexo 2 se encuentran las diferentes resoluciones de este órgano plenario en el caso de Siria.

\section{Consejo de Derechos Humanos}

El Consejo de Derechos Humanos ha sido uno de los órganos más activos en la guerra civil siria. Esta institución ha emitido treinta y ocho documentos, de los cuales diecinueve son reportes, dieciocho son resoluciones y una carta proveniente del secretario general de las Naciones Unidas que transmitía una actualización de los crímenes del EI contra los yazidíes.

Los reportes publicados por el Consejo de Derechos Humanos, en su mayoría, están dedicados a denunciar las graves violaciones de derechos humanos cometidas por las organizaciones terroristas y el gobierno sirio. Entre los crímenes de guerra que el Consejo de Derechos Humanos logró detectar están: el uso de armas químicas; el empleo del hambre y las violaciones de mujeres como un arma de guerra; las torturas; los ataques sin discriminación hacia hospitales, colegios y jardines; la destrucción de patrimonio de la humanidad (en el caso de Alepo); las detenciones arbitrarias; y los asesinatos a prisioneros sin un debido juicio, entre otros crímenes.

En definitiva, el Consejo de Derechos Humanos logró hacer evidentes las consecuencias que pueden llegar a causar la inacción y el bloqueo interno del CSNU. De igual manera, puso de manifiesto lo complejas que son la resolución de los conflictos y la reconciliación nacional, cuando se ponen los intereses económicos y políticos por encima de los derechos fundamentales de los hombres, de la dignidad y el valor de las personas.

En definitiva, la acción de la Organización de las Naciones Unidas en el caso de la guerra civil siria se puede clasificar como agridulce. Si bien es cierto que el CSNU no actuó de manera rápida y ágil para mantener la paz y la seguridad internacionales, así como tampoco para proteger a la humanidad del flagelo de la guerra, sí se puede resaltar la manera como la AG, con su trabajo mancomunado con la Liga Árabe y el Consejo de Derechos Humanos, lograron encontrar soluciones creativas que permitieran aminorar las consecuencias para la población civil. 


\section{Evolución y resolución del conflicto}

Hasta el primer semestre de 2020, el nivel de acciones bélicas en la guerra civil siria ha decrecido, pero eso no significa que el conflicto se haya acabado. El EI fue reducido a su mínima expresión luego de los múltiples ataques armados realizados por Rusia, el Ejército Kurdo, Estados Unidos y la coalición. En consecuencia, las pocas unidades que quedan de esta organización terrorista se encuentran en pequeñas zonas de Siria y en territorio Irakuí.

No obstante, el conflicto armado continúa, sin importar la expansión de la pandemia de la COVID-19. Los actores que se mantienen en enfrentamiento son: las fuerzas del gobierno sirio, un reducido grupo del EI, el Ejército Kurdo, algunas fuerzas rebeldes y los ejércitos turco e israelí. Si bien es cierto que los grupos terroristas fueron, en su mayoría, liquidados o reducidos y que el Ejército del gobierno sirio ya tiene el dominio de la casi totalidad del territorio, la ciudad de Idlib, que está situada en el noroeste de Siria y que comparte frontera con Turquía, se ha convertido ahora en escenario de la guerra, como se evidencia en la figura 4.

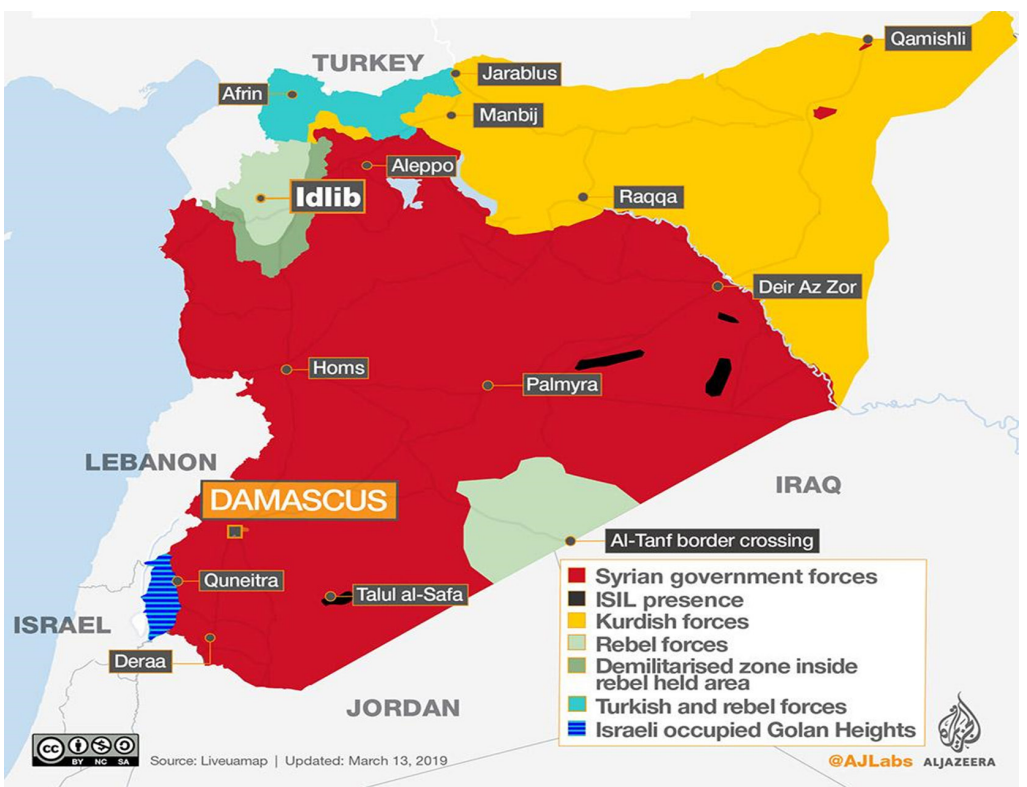

Figura 4. Actores de la guerra civil en 2020

Fuente: Najjar (2019) 
De tal forma que, ante las nuevas circunstancias, la dinámica de la guerra civil siria cambió, pues, luego de que la administración del presidente Trump decidiera quitarle el respaldo al Ejército $\mathrm{Kurdo}^{20}$, en razón de que Estados Unidos está reduciendo sus costos para poder hacerle frente a China, Turquía ha aprovechado para atacar directamente al Ejército kurdo, pueblo que lleva años pidiendo ser un Estado autónomo, lo que afecta directamente el territorio de Turquía (Moroni, 2016). De igual manera, Israel —al observar que su principal socio se retiraba de manera progresiva del conflicto y de que Siria junto con Irán resultaron favorecidos por la presencia de Rusia como un actor equilibrador de la región — ha realizado bombardeos en territorio sirio argumentando que en esas zonas se encuentran ubicados hombres armados de Hizbulah que apuntan a atacar la soberanía de Israel.

Así pues, ante la retirada progresiva de Washington de la zona, el Ejército Kurdo ha realizado una alianza con Rusia y Siria, sus antiguos enemigos, con el fin de defenderse de los ataques armados turcos. Esto ha traído dos consecuencias; la primera, Moscú ha logrado fortalecerse más en la región, ya que no solo acuerda un trato con un antiguo aliado de Washington, sino que, también, se ha convertido, a solicitud de Israel, en un intermediador entre este país e Irán para que Hizbulah abandone los ataques contra Tel-Aviv (Kozhanov, 2019). La segunda consecuencia, es que la guerra civil siria parece tener ahora una alta probabilidad de convertirse en un conflicto bélico interestatal. A este respecto, resultan preocupantes los enfrentamientos registrados entre el Ejército ruso y el turco durante los meses de febrero y marzo de 2020.

En consecuencia, hasta este momento, la resolución del conflicto no se avizora en el futuro cercano. La crisis de refugiados continuará e incluso podría empeorar, debido a la expansión del SARS-COV-2 y el juego político que se mantiene en la región de Oriente Próximo, que seguirá presente con las alianzas y contraalianzas conformadas para que los diferentes bandos logren sus respectivos intereses.

20 Con el fin de unir fuerzas para debilitar al EI, Estados Unidos apoyó militarmente al Ejército Kurdo para que de manera conjunta pudieran atacar a esta organización terrorista. Es así que, con la intermediación de Washington, Turquía no atacó al Ejército Kurdo, lo que le permitió a este último accionar libremente en cercanías a la frontera turca. 
A manera de conclusión, la guerra civil siria, que inició en marzo de 2011 y que ha durado más de nueve años, es un fiel reflejo de las guerras de la globalización que resultan del debilitamiento del Estado al perder el monopolio de las armas, del agotamiento de los ciudadanos de un modelo económico y político que va en contravía de sus intereses y de la privatización de la violencia. De igual manera, es un claro ejemplo de las nuevas guerras, pues en ellas se encuentran actores no estatales y estatales, con estrategias y tácticas de guerra asimétricas y con diferentes objetivos. Esta situación hace que la guerra se perpetúe y que no existan ganadores, pero sí perdedores absolutos concentrados siempre en la población civil que, en últimas, es la que debe enfrentarse a los desplazamientos forzados, a las hambrunas y a las peores barbaries de la guerra.

Por otro lado, el conflicto bélico sirio evidencia las fallas que tiene la estructura de la seguridad colectiva, que está cimentada en las relaciones interestatales y el concepto de soberanía - entendido como un atributo inherente al Estado_- y no en las nuevas dinámicas de la vida internacional. Esta situación, además, demostró y agudizó un debate internacional que gira alrededor de cuatro temas: 1) la dificultad tanto para aplicar el principio de 'proteger' en zonas de gran interés geopolítico como para acabar con la desconfianza de los Estados acerca de la posibilidad de que este mecanismo sea utilizado con fines políticos para interferir en asuntos internos; 2) la necesidad de compartir las cargas económicas de los refugiados; 3) el papel de las agencias humanitarias y de la gobernanza global para brindar respuestas a las víctimas durante los procesos de negociación entre los actores; y 4) la aplicación, por parte de las Naciones Unidas, de estrategias que en anteriores ocasiones han demostrado ser erróneas para generar posibles soluciones, puesto que, la mayoría de veces, provienen de élites políticas cuyos intereses están en discordancia con las necesidades de la población civil.

Ante el bloqueo interno del CSNU en la guerra civil siria, urge una reforma a este órgano en dos direcciones, en primer lugar, debería aumentar el número de los miembros, con el fin de propiciar una representación más democrática, equitativa y ajustada a las nuevas dinámicas de la vida internacional, $y$, en segundo lugar, es necesario mejorar los métodos de trabajo del CSNU, con el objetivo de aumentar la transparencia y evitar los bloqueos por vetos. 
En términos geopolíticos, la guerra civil siria profundizó el declive relativo de Estados Unidos en la región, mientras que a Rusia le permitió posicionarse en esa zona, actuar como una potencia y convertirse en un actor crucial para solucionar del conflicto armado. De igual manera, a pesar de algunos problemas económicos, pero con bastante sagacidad por parte del presidente Vladimir Putin, Rusia consiguió su objetivo político de mantener a Bashar al-Asad en el poder; mientras que Washington no logró su objetivo político de derrocar al mandatario sirio.

Por último, la actuación de las Naciones Unidas en la guerra civil siria se puede catalogar como agridulce, pues, si bien es cierto que el CSNU no logró cumplir su principal objetivo de "mantener la paz y la seguridad internacionales", no se puede desconocer la actuación de la Asamblea General y el Consejo de Derechos Humanos que, de manera conjunta, trabajaron también con la organización regional de la Liga Árabe. Esta interesante interacción se plantea como un nuevo puente para encontrar soluciones al problema de la parálisis del CSNU, producida por el juego de intereses geopolíticos de las potencias miembros.

\section{Referencias}

Álvarez-Ossorio, I. (2017). Siria: revolución, sectarismo y yihad. Catarata.

Badie, B., \& Vidal, D. (2016). Nouvelles guerres. Comprendre les conflits du XXe siècle. Éditions La Découverte.

Bauman, Z., \& Bordoni, C. (2016). Estado de crisis. Ediciones Paidós.

Cebada, A. (2017). Las respuestas de la comunidad internacional a los conflictos internacionales contemporáneos: el caso de Siria. Cuadernos de estrategia, (188), 223-248.

Chesterman, S. (Ed.). (2001). Civilians in War. Lynne Rienner Publishers.

David, C. (2013). La guerre et la paix. Approches et enjeux de la sécurité et de la stratégie. Presses de Sciences Po.

De Currea-Lugo, V. (2019). Siria. Donde el odio desplazó a la esperanza. Editorial Aguilar.

Goutalier, M. (2017). Quand le printemps brouille les cartes, une histoire stratégique des frontières arabes. Éditions du félin.

Gutiérrez, C. (2015). El conflicto en Siria (2011-2014) a la luz del derecho internacional y de la (geo) política. Revista UNISCI, (37), 99-131.

Haass, R. (2009). War of Necessity, War of Choice. A Memoir of Two Irak Wars. Simon \& Schuster. 
Evan, G., Sahnoun, M., Côté-Harper, G., Hamilton, L., y Ignatieff, M. (2001). Responsibility to protect: report of the International Commission on Intervention and State Sovereignty. IDRC, Ottawa, ON, CA. Kaldor, M. (2013). In Defense of New Wars. Stability: International Journal of Security and Development, 2(1), 1-16. https://www.stabilityjournal.org/articles/10.5334/sta.at/

Karlin, M., \& Wittes, T. (2019). America's Middle East Purgatory. The case for doing less. Foreign Affairs.

Kozhanov, N. (2019). Russia’s Difficult Balancing Act Between Iran And Israel. Aljazeera. https://www.aljazeera.com/indepth/opinion/russia-difficult-balancing-act-iran-israel-200129193640167.html

McCarthy, N. (2018). Casualties of Explosive Violence in 2017. Statista. https://www.statista. $\mathrm{com} /$ chart/13505/casualties-of-explosive-violence-in-2017

McCarthy, N. (2019). The Rise and Fall Of ISIS. Statista. https://www.statista.com/chart/20255/ the-rise-and-fall-of-isis

Mello, P. (2010). In Search of New Wars: The Debate About A Transformation of War. Euroepan Journal of International Relations, 16(2), 297-309.

Moroni, D. (2016). Albani, Leandro (2015). Revolución en el Kurdistán: La otra guerra contra el Estado Islámico. Claroscuro, 15, 260-265.

Mulroy, M., \& Oehlerich, E. (2020). Russia's Middle East: You Probe with Bayonets. If you find mush, you proceed. Middle East Institute.

Naciones Unidas. (1945). Carta de las Naciones Unidas. Naciones Unidas. https://www.un.org/ es/charter-united-nations

Naciones Unidas. (2012). Carta de las Naciones Unidas. Geoportal. https://www.un.org/Depts/ Cartographic/map/profile/syria.pdf

Najjar, F. (2019). New Front in Syria’s War: Why Manbij Matters. Aljazeera. https://www. aljazeera.com/news/2019/10/front-syria-war-manbij-matters-191015143157365.html

Nye, J. (2009). Get Smart: Combining Hard and Soft Power. Foreign Affairs, 88(4), 160-163.

Roig, C. (2017). Estado Islámico: la amenaza continúa. La ideología que sustenta al grupo terrorista conserva su capacidad para golpear en Europa y en todo el mundo. La Vanguardia. https://reportajes.lavanguardia.com/estado-islamico-isis

Rumer, E. (2019). The Primakov (Not Gerasimov) Doctrine in Action. Carnegie Endowment for International Peace. https://carnegieendowment.org/2019/06/05/primakov-not-gerasimov-doctrine-in-action-pub-79254

Sáenz, P. (2012). Las Naciones Unidas ante el conflicto de Siria. Instituto Español de Estudios Estratégicos. http://www.ieee.es/Galerias/fichero/docs_opinion/2012/DIEEEO93-2012_ SiriayNNUU_PazAndresSStaMx.pdf

Salazar, M. (2019). Conflictos y crímenes al amparo del Derecho Internacional. Foreign Affairs: Latinoamérica, 19(3), 2-9.

Stiglitz, J., \& Bilmes, L. (2008). La guerra de los tres billones de dólares. El coste real del conflicto en Irak. Taurus. 


\section{Bibliografía consultada}

Brzoska, M. (2004). 'New wars' discourse in Germany. Journal of Peace Research, 41(1), 107-117.

Díaz, L., \& Bachi, D. (2019). El caso de Siria: lagunas de protección y asistencia a personas desplazadas en contextos de conflictos armados. Foreing Affairs: Latinoamérica, 19(3), 20-28.

\section{Anexo 1}

Tabla 1. Resoluciones del Consejo de Seguridad de Naciones Unidas para la guerra civil siria

\begin{tabular}{|c|c|c|}
\hline Fecha & Resolución & Resumen \\
\hline $\begin{array}{l}14 \text { de julio } \\
\text { de } 2014\end{array}$ & $\begin{array}{l}\text { Resolución } \\
2165\end{array}$ & $\begin{array}{l}\text { Se autoriza, sin consentimiento del gobierno sirio, a } \\
\text { acceder al territorio de ese país para que la ONU y } \\
\text { sus socios utilicen las rutas, a través de las líneas del } \\
\text { conflicto y los cruces fronterizos, para bridar ayuda } \\
\text { humanitaria. Decide, de igual manera, establecer un } \\
\text { mecanismo de vigilancia bajo la autoridad del secre- } \\
\text { tario general de las Naciones Unidas. Las dos deci- } \\
\text { siones tuvieron un plazo de } 180 \text { días. }\end{array}$ \\
\hline $\begin{array}{l}15 \text { de agosto } \\
\text { de } 2014\end{array}$ & $\begin{array}{c}\text { Resolución } \\
2170\end{array}$ & $\begin{array}{l}\text { Condenó a los grupos del EI y Al-Nusra por el reclu- } \\
\text { tamiento de combatientes extranjeros y enumeró a } \\
\text { seis personas que están vinculados a grupos terroristas } \\
\text { de Al-Qaeda. }\end{array}$ \\
\hline $\begin{array}{l}24 \\
\text { de septiembre } \\
\text { de } 2014\end{array}$ & $\begin{array}{c}\text { Resolución } \\
2178\end{array}$ & $\begin{array}{l}\text { Amplió el marco de la anterior resolución con rela- } \\
\text { ción a la lucha contra el terrorismo y, en ese sentido, } \\
\text { enfocó la exigencia más fuerte hacia los Estados, lo } \\
\text { que recuerda su compromiso de hacer cumplir la } \\
\text { resolución } 1373 \text { de } 2001 \text { respecto a la lucha contra } \\
\text { el terrorismo. }\end{array}$ \\
\hline $\begin{array}{l}17 \\
\text { de diciembre } \\
\text { de } 2014\end{array}$ & $\begin{array}{c}\text { Resolución } \\
2191\end{array}$ & $\begin{array}{l}\text { Renueva la autorización para que la ONU y sus } \\
\text { aliados puedan cruzar las líneas del conflicto y los } \\
\text { cruces fronterizos para brindar ayuda humanitaria. }\end{array}$ \\
\hline $\begin{array}{c}12 \text { de febrero } \\
\text { de } 2015\end{array}$ & $\begin{array}{l}\text { Resolución } \\
2199\end{array}$ & $\begin{array}{l}\text { Se centra en el financiamiento ilícito del EI y del } \\
\text { Frente Al-Nusra, que se realiza a través de exporta- } \\
\text { ciones de petróleo, tráfico del patrimonio cultural y } \\
\text { donaciones externas. }\end{array}$ \\
\hline
\end{tabular}




\begin{tabular}{|c|c|c|}
\hline Fecha & Resolución & Resumen \\
\hline $\begin{array}{l}6 \text { de marzo } \\
\text { de } 2015\end{array}$ & $\begin{array}{l}\text { Resolución } \\
2209\end{array}$ & $\begin{array}{l}\text { Condenó el uso de productos químicos, pero sin atri- } \\
\text { buir algún culpable. De igual manera, destaca que } \\
\text { los responsables de estos tipos de ataques deberán } \\
\text { responder. }\end{array}$ \\
\hline $\begin{array}{l}7 \text { de agosto } \\
\text { de } 2015\end{array}$ & $\begin{array}{l}\text { Resolución } \\
2235\end{array}$ & $\begin{array}{l}\text { Solicitó al secretario general de las Naciones Unidas } \\
\text { y al director de la Organización sobre las Armas } \\
\text { Químicas, el establecimiento de un mecanismo de } \\
\text { investigación conjunto para determinar la responsa- } \\
\text { bilidad por el uso de armas químicas. }\end{array}$ \\
\hline $\begin{array}{l}20 \\
\text { de noviembre } \\
\text { de } 2015\end{array}$ & $\begin{array}{l}\text { Resolución } \\
2249\end{array}$ & $\begin{array}{l}\text { Pidió a todos los Estados miembros tomar las medidas } \\
\text { necesarias en el territorio sirio para evitar que el EI } \\
\text { lograra actos terroristas y otras organizaciones, como } \\
\text { Al-Qaeda. }\end{array}$ \\
\hline $\begin{array}{l}18 \\
\text { de diciembre } \\
\text { de } 2015\end{array}$ & $\begin{array}{l}\text { Resolución } \\
2254\end{array}$ & $\begin{array}{l}\text { Se tomó por unanimidad y es la primera resolución } \\
\text { que se centra en la solución política de la crisis siria. }\end{array}$ \\
\hline $\begin{array}{l}22 \\
\text { de diciembre } \\
\text { de } 2015\end{array}$ & $\begin{array}{l}\text { Resolución } \\
\quad 2258\end{array}$ & $\begin{array}{l}\text { Renovó la autorización para el ingreso de ayuda } \\
\text { humanitaria a través de las líneas fronterizas y del } \\
\text { conflicto armado. Asimismo, hizo un llamado a los } \\
\text { Estados para que previnieran el flujo de combatientes } \\
\text { terroristas extranjeros dentro y fuera de Siria. }\end{array}$ \\
\hline $\begin{array}{l}26 \text { de febrero } \\
\text { de } 2016\end{array}$ & $\begin{array}{l}\text { Resolución } \\
2268\end{array}$ & $\begin{array}{l}\text { Aprobó el cese de hostilidades y pidió reanudar las } \\
\text { negociaciones políticas. }\end{array}$ \\
\hline $\begin{array}{l}31 \text { de octubre } \\
\text { de } 2016\end{array}$ & $\begin{array}{l}\text { Resolución } \\
\quad 2314\end{array}$ & $\begin{array}{l}\text { Extendió el mandato del Mecanismo de Investigación } \\
\text { Conjunta, entre Naciones Unidas y la Organización } \\
\text { sobre las Armas Químicas, hasta el } 18 \text { de noviembre } \\
\text { de } 2016 \text {. }\end{array}$ \\
\hline $\begin{array}{l}17 \\
\text { de noviembre } \\
\text { de } 2016\end{array}$ & $\begin{array}{l}\text { Resolución } \\
2319\end{array}$ & $\begin{array}{l}\text { Renovó el mandato del Mecanismo de Investigación } \\
\text { Conjunta, entre Naciones Unidas y la Organización } \\
\text { sobre las Armas Químicas, por un año más. }\end{array}$ \\
\hline $\begin{array}{l}19 \\
\text { de diciembre } \\
\text { de } 2016\end{array}$ & $\begin{array}{l}\text { Resolución } \\
\quad 2328\end{array}$ & $\begin{array}{l}\text { Exigió el acceso de Naciones Unidas a Alepo para } \\
\text { monitorear la situación en esta ciudad. }\end{array}$ \\
\hline $\begin{array}{l}21 \\
\text { de diciembre } \\
\text { de } 2016\end{array}$ & $\begin{array}{l}\text { Resolución } \\
\quad 2332\end{array}$ & $\begin{array}{l}\text { Renovó la autorización del cruce de líneas fronterizas } \\
\text { y de guerra hasta el } 10 \text { de enero de } 2018 \text {. }\end{array}$ \\
\hline
\end{tabular}




\begin{tabular}{|c|c|c|}
\hline Fecha & Resolución & Resumen \\
\hline $\begin{array}{l}31 \\
\text { de diciembre } \\
\text { de } 2016\end{array}$ & $\begin{array}{l}\text { Resolución } \\
\quad 2336\end{array}$ & $\begin{array}{l}\text { Acogió con beneplácito los esfuerzos de Rusia y } \\
\text { Turquía para lograr poner fin a la violencia en Siria y } \\
\text { dar inicio a un proceso político. }\end{array}$ \\
\hline $\begin{array}{l}19 \\
\text { de diciembre } \\
\text { de } 2017\end{array}$ & $\begin{array}{l}\text { Resolución } \\
2393\end{array}$ & $\begin{array}{l}\text { Renovó la autorización para la entrega de ayudas } \\
\text { transfronterizas. }\end{array}$ \\
\hline $\begin{array}{l}24 \text { de febrero } \\
\text { de } 2018\end{array}$ & $\begin{array}{l}\text { Resolución } \\
2401\end{array}$ & $\begin{array}{l}\text { Fue adoptada por unanimidad y exigía el cese de } \\
\text { hostilidades en Siria. }\end{array}$ \\
\hline $\begin{array}{l}13 \\
\text { de diciembre } \\
\text { de } 2018\end{array}$ & $\begin{array}{l}\text { Resolución } \\
\quad 2449\end{array}$ & $\begin{array}{l}\text { Fue preparada por Suecia y Kuwait, apuntaba a } \\
\text { renovar la autorización del acceso humanitario trans- } \\
\text { fronterizo en Siria. }\end{array}$ \\
\hline $\begin{array}{l}25 \text { de enero } \\
\text { de } 2020\end{array}$ & $\begin{array}{l}\text { Resolución } \\
\quad 2504\end{array}$ & $\begin{array}{l}\text { Autorizó la ayuda humanitaria a través de dos cruces } \\
\text { fronterizos, Bab al-Salam y Bab al-Hawa, durante seis } \\
\text { meses. }\end{array}$ \\
\hline
\end{tabular}

\section{Anexo 2}

Tabla 2. Resolución de la Asamblea General de las Naciones Unidas

\begin{tabular}{|c|c|c|}
\hline $\begin{array}{l}19 \\
\text { de diciembre } \\
\text { de } 2011\end{array}$ & $\begin{array}{l}\text { A/RES/66/ } \\
176\end{array}$ & $\begin{array}{l}\text { Condenó la violencia en Siria y pidió la plena imple- } \\
\text { mentación de la iniciativa de la Liga Árabe de noviembre } \\
\text { de } 2011 \text {. }\end{array}$ \\
\hline $\begin{array}{l}16 \text { de febrero } \\
\text { de } 2012\end{array}$ & $\begin{array}{l}\text { A/RES/66/ } \\
253\end{array}$ & $\begin{array}{l}\text { Solicitó al secretario general designar un enviado espe- } \\
\text { cial para Siria. }\end{array}$ \\
\hline $\begin{array}{l}3 \text { de agosto } \\
\text { de } 2012\end{array}$ & $\begin{array}{l}\text { A/RES/66/ } \\
253 \mathrm{~B}\end{array}$ & $\begin{array}{l}\text { Deploró el fracaso del CSNU en su actuar sobre Siria y } \\
\text { pidió una solución política. }\end{array}$ \\
\hline $\begin{array}{l}15 \text { de mayo } \\
\text { de } 2013\end{array}$ & $\begin{array}{l}\text { A/RES/67/ } \\
262\end{array}$ & $\begin{array}{l}\text { Condenó enérgicamente la violencia discriminatoria } \\
\text { del gobierno sirio contra la población civil y acogió con } \\
\text { beneplácito la creación de la Coalición Nacional para } \\
\text { las Fuerzas Revolucionarias y de Oposición Siria, como } \\
\text { interlocutor necesario para una transición política. }\end{array}$ \\
\hline $\begin{array}{l}18 \\
\text { de diciembre } \\
\text { de } 2013\end{array}$ & $\begin{array}{l}\text { A/RES/68/ } \\
182\end{array}$ & $\begin{array}{l}\text { Condenó las violaciones de los derechos humanos en } \\
\text { Siria e instó al CSNU a tomar medidas para poner fin a } \\
\text { las violaciones. }\end{array}$ \\
\hline
\end{tabular}




\begin{tabular}{|c|c|c|}
\hline $\begin{array}{l}2 \\
\text { de noviembre } \\
\text { de } 2015\end{array}$ & $\begin{array}{l}\text { A/C. } 3 / 70 / \\
\text { L. } 47\end{array}$ & $\begin{array}{l}\text { Resolución redactada por Arabia Saudí que condena a } \\
\text { Siria y al EI y lamenta que no se haya aprobado en la } \\
\text { Corte Penal Internacional un proyecto de resolución } \\
\text { con referencia a la situación de Siria. }\end{array}$ \\
\hline $\begin{array}{c}9 \text { de diciembre } \\
\text { de } 2016\end{array}$ & $\begin{array}{c}\text { A/RES/71/ } \\
130\end{array}$ & $\begin{array}{l}\text { Expresó su indignación por el escalamiento de la } \\
\text { violencia y exigió el fin, inmediato y completo, de todos } \\
\text { los ataques contra civiles y objetos civiles. }\end{array}$ \\
\hline $\begin{array}{l}21 \\
\text { de diciembre } \\
\text { de } 2016\end{array}$ & $\begin{array}{c}\mathrm{A} / \mathrm{RES} / 71 / \\
248\end{array}$ & $\begin{array}{l}\text { Estableció un mecanismo internacional, imparcial } \\
\text { e independiente, para ayudar en la investigación y el } \\
\text { enjuiciamiento de los responsables de los delitos más } \\
\text { graves de derecho internacional cometidos en Siria. }\end{array}$ \\
\hline
\end{tabular}

